\title{
Emission factor ratios, SOA mass yields, and the impact of vehicular emissions on SOA formation
}

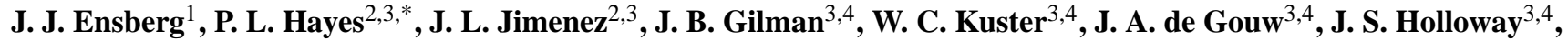

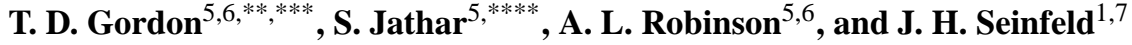 \\ ${ }^{1}$ Division of Chemistry and Chemical Engineering, California Institute of Technology, Pasadena, CA, USA \\ ${ }^{2}$ Department of Chemistry and Biochemistry, University of Colorado, Boulder, CO, USA \\ ${ }^{3}$ Cooperative Institute for Research in Environmental Sciences, University of Colorado Boulder, Boulder, CO, USA \\ ${ }^{4}$ National Oceanic and Atmospheric Administration Earth System Research Laboratory, Chemical Sciences Division, \\ 325 Broadway, Boulder, CO 80304, USA \\ ${ }^{5}$ Center for Atmospheric Particle Studies, Carnegie Mellon University, Pittsburgh, PA 15213, USA \\ ${ }^{6}$ Engineering and Public Policy, Carnegie Mellon University, Pittsburgh, PA 15213, USA \\ ${ }^{7}$ Division of Engineering and Applied Science, California Institute of Technology, Pasadena, CA, USA \\ * now at: Department of Chemistry, University of Montreal, Montreal, Quebec, Canada \\ ***now at: National Oceanic and Atmospheric Administration Earth System Research Laboratory, Chemical Sciences \\ Division, 325 Broadway, Boulder, CO 80304, USA \\ *** now at: Cooperative Institute for Research in Environmental Sciences, University of Colorado Boulder, \\ Boulder, CO, USA \\ **** now at: Department of Civil and Environmental Engineering, University of California at Davis, Davis, CA, USA
}

Correspondence to: J. H. Seinfeld (seinfeld@ caltech.edu)

Received: 17 September 2013 - Published in Atmos. Chem. Phys. Discuss.: 28 October 2013

Revised: 29 January 2014 - Accepted: 1 February 2014 - Published: 7 March 2014

\begin{abstract}
The underprediction of ambient secondary organic aerosol (SOA) levels by current atmospheric models in urban areas is well established, yet the cause of this underprediction remains elusive. Likewise, the relative contribution of emissions from gasoline- and diesel-fueled vehicles to the formation of SOA is generally unresolved. We investigate the source of these two discrepancies using data from the 2010 CalNex experiment carried out in the Los Angeles Basin (Ryerson et al., 2013). Specifically, we use gasphase organic mass (GPOM) and CO emission factors in conjunction with measured enhancements in oxygenated organic aerosol (OOA) relative to $\mathrm{CO}$ to quantify the significant lack of closure between expected and observed organic aerosol concentrations attributable to fossil-fuel emissions. Two possible conclusions emerge from the analysis to yield consistency with the ambient data: (1) vehicular emissions are not a dominant source of anthropogenic fossil SOA in the Los Angeles Basin, or (2) the ambient SOA mass yields used to determine the SOA formation potential of vehicular emissions
\end{abstract}

are substantially higher than those derived from laboratory chamber studies.

\section{Introduction}

Emissions in California have significantly decreased over time (Warneke et al., 2012). However, two important issues concerning the sources of organic aerosol in urban areas remain generally unresolved: (1) what is the relative impact of emissions from gasoline- and diesel-fueled vehicles on the formation of secondary organic aerosol (SOA) (Bahreini et al., 2012; Gentner et al., 2012; Hayes et al., 2013); and (2) what is the cause of the significant underprediction of SOA levels by existing atmospheric models in urban areas (de Gouw et al., 2005; Volkamer et al., 2006; Johnson et al., 2006; de Gouw et al., 2008; Kleinman et al., 2008; Matsui et al., 2009)? We investigate the source of these two issues based on a detailed analysis of data in the Los Angeles 
atmosphere; the procedures we use to analyze these issues are likely to be applicable to major urban areas worldwide. Based on the highly resolved speciation profiles of gasoline and diesel fuel, Gentner et al. (2012) estimated that diesel exhaust is responsible for 2-7 times more SOA than gasoline exhaust in California. However, from measurements of the weekday-weekend cycle of organic aerosol, black carbon, single-ring aromatic hydrocarbons, $\mathrm{CO}$, and oxides of nitrogen $\left(\mathrm{NO}_{\mathrm{x}}=\mathrm{NO}+\mathrm{NO}_{2}\right)$ in the Los Angeles (L.A.) Basin, Bahreini et al. (2012) and Hayes et al. (2013) conclude that emissions from gasoline-fueled vehicles dominate the SOA budget. Notably, the conclusions of Bahreini et al. (2012) and Hayes et al. (2013) are based on the observation that diesel activity has a clear weekday-weekend cycle, whereas measured $\mathrm{CO}$ mixing ratios and the enhancement of SOA with respect to $\mathrm{CO}$ exhibit virtually no weekday-weekend cycle when segregated by photochemical age. Nevertheless, as acknowledged by Hayes et al. (2013), the conclusions of Bahreini et al. (2012) and Hayes et al. (2013) presume that vehicular emissions are the dominant source of anthropogenic fossil SOA in the L.A. Basin.

\section{Ambient measurements}

Ambient data $\left(\mathrm{CO}, \mathrm{NO}_{\mathrm{x}}, \mathrm{NO}_{\mathrm{y}}, \mathrm{O}_{3}, \mathrm{OH}, \mathrm{VOCs}\right.$, submicron nonrefractory (nrPM1) organic aerosol) at the Pasadena ground site were collected during the 2010 CalNex experiment (Ryerson et al., 2013). The CalNex Pasadena ground site was located $18 \mathrm{~km}$ northeast of downtown Los Angeles on the California Institute of Technology (Caltech) campus in Pasadena, California $\left(34.1406^{\circ} \mathrm{N}, 118.1225^{\circ} \mathrm{W}\right.$, $236 \mathrm{~m}$ a.m.s.l.). The measurement period was 15 May 2010, 00:00-16 June 2010, 00:00 (local time). The prevailing wind direction during daytime in Pasadena was from the southwest due to the sea breeze, which brought air masses from the Pacific Ocean across central Los Angeles to Pasadena.

$\mathrm{CO}$ concentrations were measured by two vacuum-UV resonance fluorescence instruments (AL5001 \& AL5002, Aerolaser) (Gerbig et al., 1999). CO emissions in Los Angeles are attributable almost exclusively to vehicular emissions (Griffin et al., 2007, http://www.arb.ca.gov/ app/emsinv/emssumcat.php), with minor contributions from cooking and oxidation of biogenic emissions (Hayes et al., 2013; Allan et al., 2010). A Fluorescence Assay by Gas Expansion (FAGE) instrument was utilized to determine the $\mathrm{OH}$ concentration (Dusanter et al., 2009). The concentration of $\mathrm{O}_{3}$ was measured by UV differential absorption (49c Ozone Analyzer, Thermo Scientific). An in situ Gas Chromatography Mass Spectrometry (GC-MS) instrument provided the mixing ratios for a variety of VOCs (Gilman et al., 2009). $\mathrm{NO}_{\mathrm{x}}$ and $\mathrm{NO}_{\mathrm{y}}$ concentrations were measured using chemiluminescence (42i- TL with Mo converter, Thermo Scientific), and $\mathrm{NO}_{2}$ was measured with Cavity Enhanced Differential Optical Absorption Spectroscopy (CE-DOAS) (Thalman and
Volkamer, 2010). Concentrations of submicron nonrefractory (nrPM1) organic aerosol particles were measured using an Aerodyne high resolution time-of-flight aerosol mass spectrometer (hereinafter referred to as AMS ) (DeCarlo et al., 2006). The OA mass spectral matrix was deconvolved into components using PMF, a receptor-based factorization model (Paatero et al., 1994). The OA (organic aerosol) components from the PMF (positive matrix factorization) analysis were identified by their mass spectra, diurnal cycles, and elemental composition, as well as by the concentration ratios and correlations of their time series with tracers. These components are (1) hydrocarbon-like organic aerosol (HOA), (2) cooking- influenced organic aerosol (CIOA), (3) local organic aerosol (LOA), (4) semi-volatile oxygenated organic aerosol (SV-OOA), and (5) low-volatility oxygenated organic aerosol (LV-OOA). The HOA component has been previously described as a surrogate for primary combustion OA, and the SV-OOA and LV-OOA components as surrogates for "fresher" and "aged" SOA, respectively. (Zhang et al., 2007; Aiken et al., 2008; Jimenez et al., 2009; Ulbrich et al., 2009). As discussed in Hayes et al. (2013), the LOA component exhibits high frequency fluctuations most likely resulting from local sources in close proximity to the Pasadena ground site. However, since LOA represents only $\sim 5 \%$ of the total OA budget, this factor is not considered further.

Figure 1 shows measured PMF factor concentrations normalized by $\mathrm{CO}$ enhancement ( $\triangle \mathrm{CO}$ is the difference between the ambient $\mathrm{CO}$ and the estimated background $\mathrm{CO}, 105 \mathrm{ppb}$ ) as functions of photochemical age (see Hayes et al. (2013) for a detailed description of how this figure was constructed). The photochemical age of the air mass over the Pasadena site was calculated by two methods: (1) from the ratio of 1,2,4trimethylbenzene to benzene concentrations, as described in Parrish et al. (2007); and (2) by defining the photochemical age as $-\log _{10}\left(\mathrm{NO}_{\mathrm{x}} / \mathrm{NO}_{\mathrm{y}}\right)$ similar to Kleinman et al. (2008). Both methods give very similar results, and all photochemical ages were calculated for reference using an average $\mathrm{OH}$ radical concentration of $1.5 \times 10^{6}$ molecules $\mathrm{cm}^{-3}$. For reference, the daily (day and night) $\mathrm{OH}$ radical concentration averaged over the entire campaign at the Pasadena site was $1.3 \times 10^{6}$ molecules $\mathrm{cm}^{-3}$. Note that the $\mathrm{OH}$ exposure, which is fully constrained by the measured evolution of the benzene / trimethylbenzene ratio, is the only quantity needed for calculating the fraction of VOC that has reacted (e.g., frac $=(1-\exp (-k \times \mathrm{OH}$-exposure $))$. Therefore, choosing a different $\mathrm{OH}$ radical concentration will not influence our results because the $\mathrm{OH}$ exposures remain the same. Owing to the formation of SOA, the OOA factors are enhanced (increased) with respect to $\triangle \mathrm{CO}$ as the photochemical age of the air mass increases. As shown in Fig. 1b, the enhancement of OOA (SV-OOA + LV-OOA) relative to $\triangle \mathrm{CO}$ after 0.45 days of photochemical processing is $48 \mu \mathrm{g} \mathrm{OOA} \mathrm{sm}^{-3}$ (ppmv CO) $)^{-1}$ (48 is the difference between 58, which occurs at 0.45 days, and 10 , which occurs at 0 days), whereas the ratio of POA (HOA + CIOA) to 

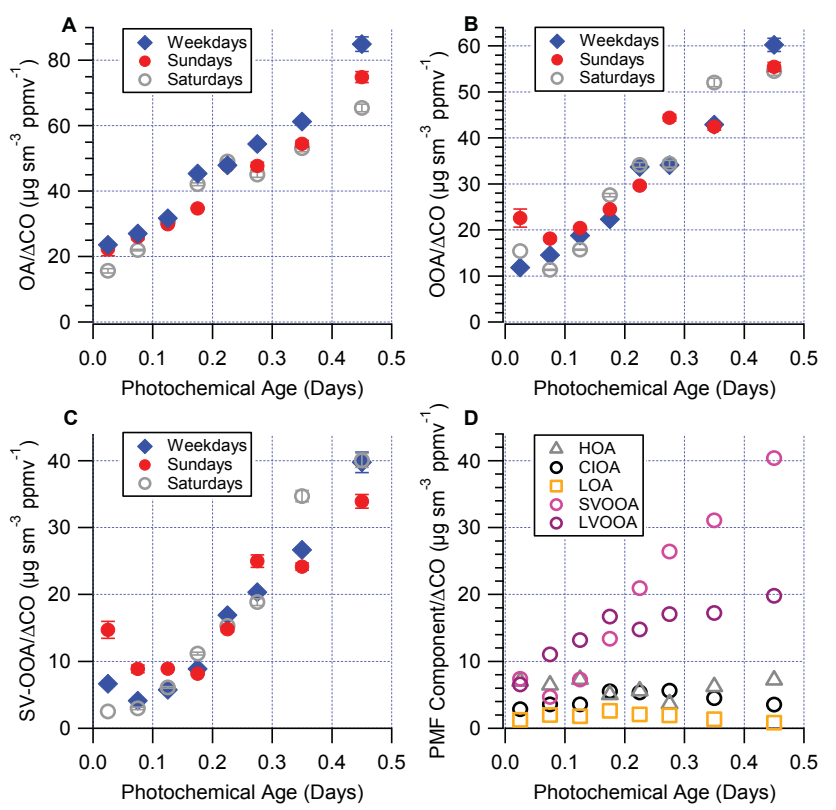

Fig. 1. Measured AMS PMF factor concentrations normalized by $\mathrm{CO}$ enhancement ( $\triangle \mathrm{CO}$ is the ambient $\mathrm{CO}$ minus the estimated background $\mathrm{CO}, 105 \mathrm{ppb}$ ) as functions of photochemical age (see Hayes et al., 2013 for a detailed description of how this figure was constructed). (A) The evolution of $\mathrm{OA} / \triangle \mathrm{CO}$ vs. photochemical age for Pasadena during CalNex separated by day of the week. Error bars indicate the standard errors. Photochemical age is determined using the method of Parrish et al. (2007). Also shown are the analogous plots for (B) OOA and (C) SV-OOA. (D) Evolution of the PMF component concentrations normalized to $\triangle \mathrm{CO}$ vs. photochemical age.

$\triangle \mathrm{CO}$ is relatively constant (i.e., no enhancement) at $9.6 \mu \mathrm{g}$ $(\mathrm{HOA}+\mathrm{CIOA}) \mathrm{sm}^{-3}(\mathrm{ppmv} \mathrm{CO})^{-1}$. Note that the average OOA enhancement corresponds to an average $\mathrm{OH}$ exposure of $58.3 \times 10^{9}$ molec cm $^{-3} \mathrm{~s}(\sim 0.45$ days $)$, and that the average POA $/ \triangle \mathrm{CO}$ value is very similar to the value of $9.4 \mu \mathrm{g} \mathrm{POA} \mathrm{sm}^{-3}(\mathrm{ppmv} \mathrm{CO})^{-1}$ assumed by both Bahreini et al. (2012) and Gentner et al. (2012).

In this study, we are primarily interested in the fraction of OOA attributable to anthropogenic fossil activity. Based on the ${ }^{14} \mathrm{C}$ analysis presented in Zotter et al. (2014), $70 \%$ of the SV-OOA enhancement corresponds to the fraction of OOA that is attributable to anthropogenic fossil-fuel activity. Some anthropogenic SOA, such as from cooking emissions, will be nonfossil. Therefore, we note that at 0.45 days of photochemical processing, $70 \%$ of the SV-OOA enhancement is equal to $\sim 25 \pm 9 \mu \mathrm{g} \mathrm{SV-OOA} \mathrm{sm}{ }^{-3}$ (ppmv CO) ${ }^{-1}$ (Fig. 1c), where $\pm 9 \mu \mathrm{g} \mathrm{SV-OOA} \mathrm{sm}{ }^{-3}$ (ppmv CO) ${ }^{-1}$ is the propagated uncertainty associated with the OOA and $\mathrm{CO}$ measurements.

\section{Results and discussion}

\subsection{Emission ratios and required SOA yields}

Fuel-sales data reported by the California Department of Transportation (http://www.dot.ca.gov/hq/tsip/otfa/tab/ documents/mvstaff/mvstaff08.pdf) indicate that diesel and gasoline fuel sales in all California counties upwind of Pasadena during 2010 represented approximately $13 \%$ and $87 \%$ of total fuel sales (county-wide) by volume, respectively. Therefore, on average, for every liter of fuel combusted on-road and upwind of Pasadena in 2010, the following can be assumed:

$\left[L_{\text {gas }}\right]=0.87 \times\left[L_{\text {fuel }}\right]$,

$\left[L_{\text {dies }}\right]=0.13 \times\left[L_{\text {fuel }}\right]$.

Figure 2a shows the chemical speciation profile and the compound-specific SOA mass yields ( $Y=\Delta$ SOA $/ \Delta$ Hydrocarbon $)$ for a composite fuel comprising $13 \%$ diesel fuel and $87 \%$ gasoline fuel (by volume), based on detailed chemical-speciation profiles (see Tables S5, S6, and S8 of Gentner et al., 2012). As shown in Fig. 2a, the 2010 composite fuel composition is dominated by species with fewer than 12 carbon atoms, with the largest contributions coming from branched alkanes and single-ring aromatics. Note that the percentages listed in the legend of Fig. 2a sum up to $\sim 90 \%$, which corresponds to the unprecedented level of mass closure Gentner et al. (2012) obtained in characterizing gasoline and diesel fuel. Gentner et al. (2012) estimated the SOA mass yields for pure gasoline and pure diesel fuel using a combination of measured SOA mass yields derived from laboratory-chamber experiments and approximate SOA mass yields based on box modeling. Based on the level of oxidation effectively constrained by experimental measurements, the SOA mass yields reported by Gentner et al. (2012) are expected to be representative of the first several generations of photochemical oxidation. The compound-specific SOA mass yields reported by Gentner et al. (2012) are given in Fig. 2b, and Fig. 2c shows the product of the estimated yields and the weight percent (by carbon) of the individual species in liquid fuel. In contrast to the cumulative distribution shown in Fig. 2a, roughly $50 \%$ of the expected SOA mass is attributable to species with fewer than 12 carbons and $50 \%$ is attributable to species with more than 12 carbons. Note that single-ring aromatics are predicted to make the most significant contribution to the SOA budget (Fig. 2c). The analysis in the present study implicitly assumes that the SOA yields from Gentner et al. (2012), which were mostly determined based on chamber experiments with individual compounds, apply to the complex L.A. atmosphere, consistent with the limited evidence available for complex precursor mixtures (Odum et al., 1997, 1996).

Vehicular exhaust emissions include water, $\mathrm{CO}, \mathrm{CO}_{2}$, $\mathrm{NO}_{\mathrm{x}}$, and partially combusted hydrocarbons, as well as a 

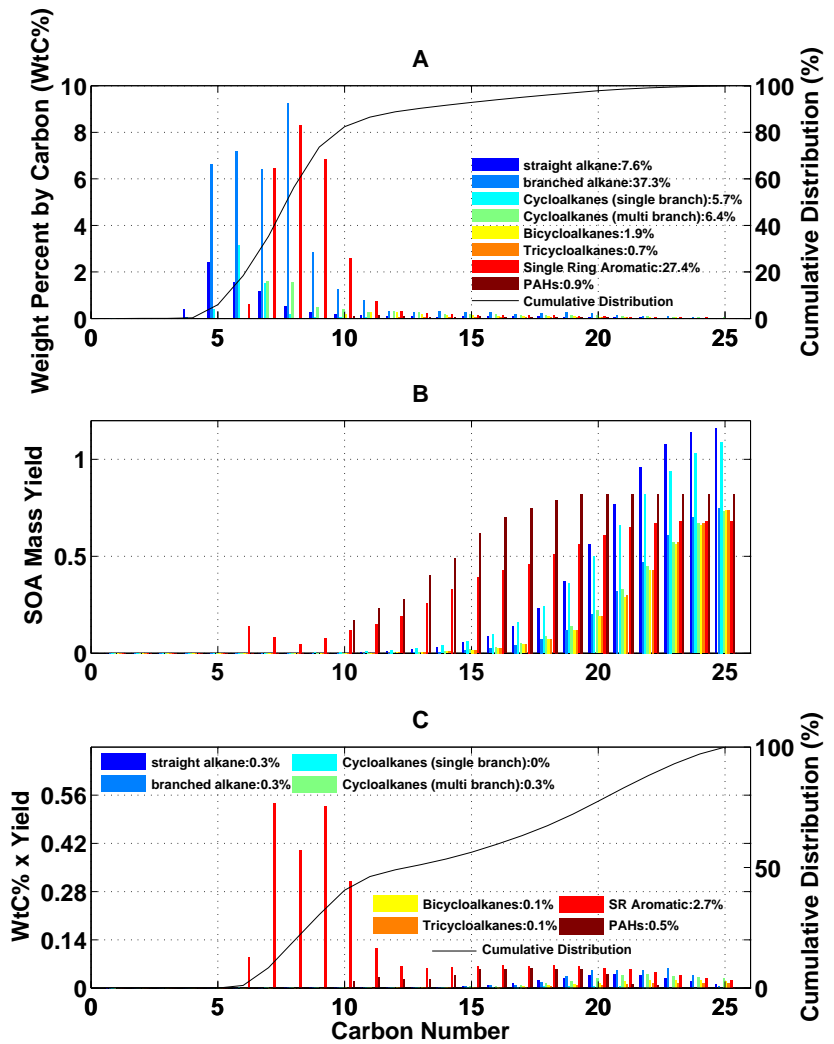

Fig. 2. Distribution of mass by chemical class based on California fuel-sale data comprising $13 \%$ diesel and $87 \%$ gasoline, by volume (top panel). Distribution of compound specific SOA mass yields (middle panel). Relative contributions of each group of species to predicted SOA, calculated as the yields multiplied by weight percent (by carbon) in liquid fuel (bottom panel). Data are from Tables S5, S6, and S8 of Gentner et al. (2012).

large contribution from unburned fuel that escapes combustion. Gentner et al. (2012) argue that unburned fuel in exhaust emissions is the dominant source of newly formed SOA attributable to vehicular activity. Emission factors reported by Gentner et al. (2012), which are based on CalNex 2010 measurements at the Caldecott Tunnel in Oakland, CA, for $\mathrm{CO}$ and for noncombusted gas-phase organic mass (GPOM) emitted in the exhaust of gasoline (gas) and diesel (dies) engines are

$$
\begin{aligned}
& \left.\mathrm{EF}_{\mathrm{CO}, \text { gas }}=14.7 \pm 5.88 \mathrm{~g} \mathrm{CO} L_{\text {gas }}\right)^{-1}, \\
& \mathrm{EF}_{\mathrm{CO}, \text { dies }}=4.5 \pm 1.80 \mathrm{~g} \mathrm{CO}\left(L_{\text {dies })^{-1}},\right. \\
& \mathrm{EF}_{\mathrm{GPOM}, \text { gas }}=0.45 \pm 0.18 \mathrm{~g} \mathrm{GPOM} L_{\text {gas })^{-1}} \\
& \mathrm{EF}_{\mathrm{GPOM}, \text { dies }}=1.01 \pm 0.40 \mathrm{~g} \mathrm{GPOM}\left(L_{\text {dies })^{-1}},\right.
\end{aligned}
$$

where the uncertainties are assumed to be $\pm 40 \%$ based on average values reported in Tables S5 and S6 of McDonald et al. (2013). Therefore, the total amount of noncombusted
GPOM and CO emitted per liter of combusted fuel is

$$
\begin{aligned}
& \mathrm{GPOM}=\mathrm{EF}_{\mathrm{GPOM}, \text { gas }} \times\left[L_{\mathrm{gas}}\right]+\mathrm{EF}_{\mathrm{GPOM}, \text { dies }} \times\left[L_{\text {dies }}\right] \\
& \mathrm{CO}=\mathrm{EF}_{\mathrm{CO}, \text { gas }} \times\left[L_{\mathrm{gas}}\right]+\mathrm{EF}_{\mathrm{CO}, \text { dies }} \times\left[L_{\text {dies }}\right] .
\end{aligned}
$$

Substituting Eqs. (1) and (2) into Eqs. (7) and (8) and dividing gives the amount of GPOM that is emitted per unit of $\mathrm{CO}$ mass emitted (defined here as $\mathrm{EF}_{\mathrm{GPOM}, \mathrm{CO}}$ ):

$$
\begin{aligned}
& \mathrm{EF}_{\mathrm{GPOM}, \mathrm{CO}}=\frac{[\mathrm{GPOM}]}{[\mathrm{CO}]}= \\
& \quad \frac{\mathrm{EF}_{\mathrm{GPOM}, \text { gas }} \times 0.87+\mathrm{EF}_{\mathrm{GPOM}, \text { diesel }} \times 0.13}{\mathrm{EF}_{\mathrm{CO}, \text { gas }} \times 0.87+\mathrm{EF}_{\mathrm{CO} \text {,diesel }} \times 0.13}, \\
& \mathrm{EF}_{\mathrm{GPOM}, \mathrm{CO}}=0.039 \pm 0.019 \mathrm{~g} \mathrm{GPOM}(\mathrm{g} \mathrm{CO})^{-1} .
\end{aligned}
$$

Converting grams to micrograms and normalizing the numerator and denominator by air volume at standard conditions (273 K and $1 \mathrm{~atm}$ ), Eq. (10) can be written as

$$
\mathrm{EF}_{\mathrm{GPOM}, \mathrm{CO}}=0.039 \pm 0.019 \mu \mathrm{g} \mathrm{GPOM} \mathrm{sm}{ }^{-3}\left(\mu \mathrm{g} \mathrm{CO} \mathrm{sm}^{-3}\right)^{-1}
$$

The $\mathrm{CO}$ emission units $\mu \mathrm{g} \mathrm{CO} \mathrm{sm}{ }^{-3}$ in Eq. (11) can be converted to ppmv $\mathrm{CO}$ by using the following conversion factor, which is applicable at $273 \mathrm{~K}$ and $1 \mathrm{~atm}$ :

$$
\begin{aligned}
& \mathrm{EF}_{\mathrm{GPOM}, \mathrm{CO}}=0.039 \pm 0.019 \mu \mathrm{g} \mathrm{GPOM} \mathrm{sm}^{-3} \\
& \left.\quad(\mu \mathrm{g} \mathrm{CO} \mathrm{sm})^{-3}\right)^{-1} \times 1250 \mu \mathrm{g} \mathrm{CO} \mathrm{sm}^{-3}\left(\mathrm{ppmv} \mathrm{CO}^{-1},\right. \\
& \mathrm{EF}_{\mathrm{GPOM}, \mathrm{CO}}=48.9 \pm 24.3 \mu \mathrm{gPOM} \mathrm{sm}^{-3}(\mathrm{ppmv} \mathrm{CO})^{-1}
\end{aligned}
$$

We assume that $\mathrm{EF}_{\mathrm{GPOM}, \mathrm{CO}}$ given by Eq. (13) is representative of the average vehicle fleet, and that the $70 \%$ of the SV-OOA concentrations that are comprised of fossil carbon at the Pasadena ground site are attributable to vehicular emissions (Bahreini et al., 2012; Hayes et al., 2013). Using $\mathrm{EF}_{\mathrm{GPOM}, \mathrm{CO}}$ and $70 \%$ of the SV-OOA enhancement $\left(25 \pm 9 \mu \mathrm{g} \mathrm{OOA} \mathrm{sm}^{-3}\left(\mathrm{ppmv} \mathrm{CO}^{-1}\right)\right.$ given in Fig. 1b, the average aggregate SOA mass yield required to obtain mass closure at the Pasadena ground site, $Y_{\text {req }}$, can be determined as follows:

$$
\begin{aligned}
Y_{\text {req }} & =\frac{\Delta \mathrm{SOA}}{\Delta \mathrm{GPOM}}=\frac{25 \pm 9 \mu \mathrm{g} \mathrm{SOA} \mathrm{sm}{ }^{-3}\left(\mathrm{ppmv} \mathrm{CO}^{-1}\right.}{48.9 \pm 24.3 \mu \mathrm{g} \mathrm{GPM} \mathrm{sm}^{-3}\left(\mathrm{ppmv} \mathrm{CO}^{-1}\right.} \\
& =51.1 \pm 31.4 \% .
\end{aligned}
$$

This required overall SOA mass yield is to be compared with the estimated yields reported in Gentner et al. (2012) (Fig. 2) for pure gasoline fuel and pure diesel fuel, which are $2.3 \pm 0.7 \%$ and $15 \pm 5 \%$, respectively. Based on the estimated yields for pure liquid gasoline and diesel fuel, the predicted SOA mass yield for a fuel comprising $87 \%$ gasoline and $13 \%$ diesel is $5.5 \%$. Note that the required SOA mass yield is a lower bound because it is based on the assumption that $100 \%$ of the GPOM reacts within 0.45 days $\left(\mathrm{OH}\right.$ exposure $=\sim 58.3 \times 10^{9}$ molec $\left.\mathrm{cm}^{-3} \mathrm{~s}\right)$ of being emitted. As shown in Table 1, the fraction of hydrocarbon reacted 
Table 1. Fraction of hydrocarbon reacted for an $\mathrm{OH}$ exposure of $58.3 \times 10^{9}$ molec $\mathrm{cm}^{-3} \mathrm{~s}$ at $298 \mathrm{~K}$ and $1 \mathrm{~atm}$. Hydrocarbons shown are abundant in a typical mixture of liquid gasoline and diesel fuel. Fraction reacted $=1-\exp \left(-k_{\mathrm{OH}} \times[\mathrm{OH}] \times t\right)$.

\begin{tabular}{|c|c|c|}
\hline Hydrocarbon & $\begin{array}{r}\text { Fraction } \\
\text { reacted }\end{array}$ & $\begin{array}{r}\text { OH reaction-rate } \\
\text { constant } \\
\left(\mathrm{cm}^{3} \mathrm{molec}^{-1} \mathrm{~s}^{-1}\right)\end{array}$ \\
\hline benzene $^{\mathrm{a}}$ & 0.069 & $1.22 \times 10^{-12}$ \\
\hline toluene $\mathrm{e}^{\mathrm{a}}$ & 0.280 & $5.63 \times 10^{-12}$ \\
\hline$m$-xylene $\mathrm{a}^{\mathrm{a}}$ & 0.740 & $2.31 \times 10^{-11}$ \\
\hline$n$-hexane $\mathrm{b}^{\mathrm{b}}$ & 0.272 & $5.45 \times 10^{-12}$ \\
\hline$n$-octane $\mathrm{e}^{\mathrm{b}}$ & 0.398 & $8.71 \times 10^{-12}$ \\
\hline$n$-dodecane $\mathrm{e}^{\mathrm{b}}$ & 0.555 & $1.39 \times 10^{-11}$ \\
\hline
\end{tabular}

${ }^{a}$ Reaction rate constants from Calvert et al. (2002).

${ }^{\mathrm{b}}$ Reaction rate constants from Atkinson (1997).

for an $\mathrm{OH}$-exposure of $58.3 \times 10^{9} \mathrm{molec}^{-3} \mathrm{~s}$ is between 0.07 and 0.74 for several hydrocarbons abundant in gasoline and diesel fuel. To account for partial reaction of the emitted hydrocarbons, we reduce each chemical constituent of the emitted GPOM (Fig. 2a) by the fraction that would react after 0.45 days of photochemical aging. The partially reacted $\mathrm{EF}_{\mathrm{GPOM}, \mathrm{CO}}$ (Eq. 13) is then determined by summing over all partially reacted GPOM components. The total fraction of GPOM reacted after 0.45 days of photochemical aging ranges from 0.66 at $100 \%$ diesel to 0.43 at $100 \%$ gasoline, and is 0.47 for fuel usage of $13 \%$ diesel and $87 \%$ gasoline (by volume). Reducing the $\mathrm{EF}_{\mathrm{GPOM}, \mathrm{CO}}$ by a factor of 0.47 increases the required yield by a factor of 2.13 $\left(Y_{\text {req }}=2.13 \times 51.1 \pm 31.4 \%=108.7 \pm 66.9 \%\right)$.

The analysis thus far is based on the county-specific fuel usage of $13 \%$ diesel and $87 \%$ gasoline (by volume). However, the dependence of the required overall SOA mass yield on any fractional fuel usage $\left(f_{\text {gas }}+f_{\text {dies }}=1\right)$ is calculated as

$$
\begin{aligned}
& \mathrm{EF}_{\mathrm{GPOM}, \mathrm{CO}}\left(f_{\text {gas }}, f_{\text {dies }}\right)= \\
& \frac{\mathrm{EF}_{\mathrm{GPOM}, \text { gas }} \times f_{\text {gas }}+\mathrm{EF}_{\mathrm{GPOM}, \text { dies }} \times f_{\text {dies }}}{\mathrm{EF}_{\mathrm{CO}, \text { gas }} \times f_{\text {gas }}+\mathrm{EF}_{\mathrm{CO} \text {,dies }} \times f_{\text {dies }}} \times \mathrm{FR}\left(f_{\text {gas }}, f_{\text {dies }}\right),(15) \\
& Y_{\text {req }}=\frac{25 \pm 9 \mu \mathrm{gOA} \mathrm{sm}{ }^{-3}(\mathrm{ppmv} \mathrm{CO})^{-1}}{\mathrm{EF}_{\mathrm{GPOM}, \mathrm{CO}}\left(f_{\text {gas }}, f_{\text {dies }}\right)}
\end{aligned}
$$

where $\operatorname{FR}\left(f_{\text {gas }}, f_{\text {dies }}\right)$ is the fraction of GPOM reacted (FR, fraction reacted) after 0.45 days of photochemical aging for a given fractional fuel usage. The predictions of Eq. (16) are shown in Fig. 3a. Note that, as a result of gasoline having a higher $\mathrm{EF}_{\mathrm{CO}}$ and a lower $\mathrm{EF}_{\mathrm{GPOM}}$ than its diesel counterpart, the required overall SOA mass yield increases as the fraction of gasoline increases. In other words, the emission ratio $\mathrm{EF}_{\mathrm{GPOM}} / \mathrm{EF}_{\mathrm{CO}}$ decreases as the fraction of gasoline use increases, thereby requiring a greater fraction of the emitted GPOM to be converted to SOA to match observations at the Pasadena ground site. Also shown in Fig. 3a are the SOA mass yields predicted, $Y_{\text {pred }}$, based on the values reported by

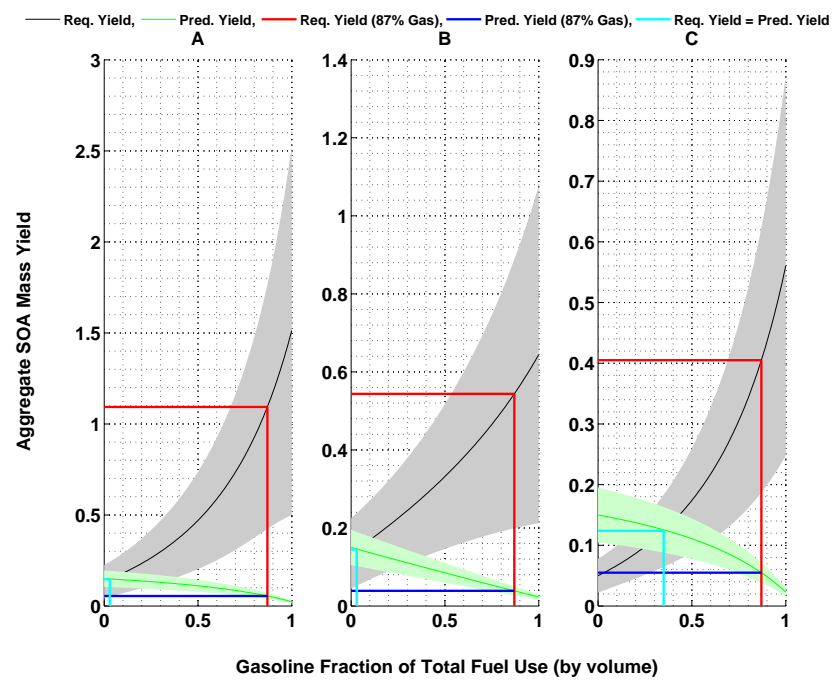

Fig. 3. Vehicular SOA mass yields compared to ambient SV-OOA mass yields assuming all fossil SV-OOA is attributable to vehicular emissions. (A) Black line: aggregate SOA mass yield required to match observations at the Pasadena ground site assuming all fossil SOA is attributable to vehicular emissions. Green line: SOA mass yield of unburned fuel (gasoline/diesel) components reported by Gentner et al. (2012). Red line: yield required for $87 \%$ gasoline and $13 \%$ diesel fuel (state-average). Blue line: SOA mass yield of liquid fuel for $87 \%$ gasoline and $13 \%$ diesel fuel (state-average). Cyan line: point at which the black line crosses the green line. (B) Same as (A) except $\mathrm{EF}_{\mathrm{GPOM}}$, gas have been increased by a factor of 2.35. (C) Same as (A) except $\mathrm{EF}_{\mathrm{GPOM}}$,gas and $\mathrm{EF}_{\mathrm{GPOM}}$, dies have both been increased by a factor of 2.7 (McDonald et al., 2013). Error bars correspond to propagated uncertainties, and all plots have been adjusted to account for partial reaction of hydrocarbons at 0.45 days of photochemical aging. Required yields are based on SV-OOA measurements and ${ }^{14} \mathrm{C}$ measurements reported in Zotter et al. (2014); Hayes et al. (2013). All quantities are plotted as functions of gasoline and diesel fuel sales (by volume).

Gentner et al. (2012) as a function of fractional fuel usage, which are calculated as

$$
\begin{aligned}
& Y_{\text {pred }}= \\
& \quad \frac{Y_{\text {gas }} \times \mathrm{EF}_{\mathrm{GPOM}, \text { gas }} \times f_{\text {gas }}+Y_{\text {dies }} \times \mathrm{EF}_{\mathrm{GPOM}, \text { dies }} \times f_{\text {dies }}}{\mathrm{EF}_{\mathrm{GPOM}, \text { gas }} \times f_{\text {gas }}+\mathrm{EF}_{\mathrm{GPOM}, \text { dies }} \times f_{\text {dies }}},
\end{aligned}
$$

where $Y_{\text {gas }}=0.023 \pm 0.007$ and $Y_{\text {dies }}=0.15 \pm 0.05$. As shown in Fig. 3a, the required and predicted SOA yields match if the fuel usage is $3 \%$ gasoline and $97 \%$ diesel, and the propagated error bars intersect when the fuel usage is $40 \%$ gasoline and $60 \%$ diesel, both of which are far from the reported fuel usage of $87 \%$ gasoline and $13 \%$ diesel. For reference, the closest any county in California comes to the required fuel usage is Glenn County (northern California) which had fuel sales that were $58 \%$ gasoline and $42 \%$ diesel. 
Table 2. Measured fleet-averaged fuel-based CO and NMHC emission factors ( $\mathrm{g} \mathrm{kg}^{-1}$ of fuel) reported by Fujita et al. (2012); Gentner et al.

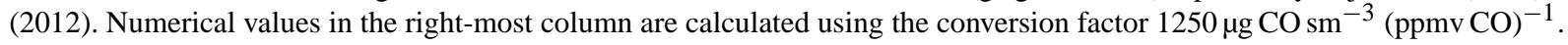

\begin{tabular}{|c|c|c|c|c|c|}
\hline $\begin{array}{l}\text { Date } \\
\text { values from Fujita et al. (2012) }\end{array}$ & $\begin{array}{r}\text { Temperature } \\
{ }^{\circ} \mathrm{F}\end{array}$ & $\begin{array}{r}\mathrm{EF}_{\mathrm{CO}} \\
\mathrm{g} \mathrm{CO} \\
(\mathrm{kg} \text { fuel })^{-1}\end{array}$ & $\begin{array}{r}\mathrm{EF}_{\mathrm{NMHC}} \\
\mathrm{g} \mathrm{NMHC} \\
(\mathrm{kg} \text { fuel })^{-1}\end{array}$ & $\begin{array}{r}\mathrm{EF}_{\mathrm{NMHC}} / \mathrm{EF}_{\mathrm{CO}} \\
\mathrm{g} \mathrm{NHMC} \\
(\mathrm{g} \mathrm{CO})^{-1}\end{array}$ & $\begin{array}{r}\mathrm{EF}_{\mathrm{NMHC}} / \mathrm{EF}_{\mathrm{CO}} \\
\mu \mathrm{g} \mathrm{NMHC} \mathrm{sm}{ }^{-3} \\
(\mathrm{ppmv} \mathrm{CO})^{-1}\end{array}$ \\
\hline 21 Aug, Sat p.m. & 95 & 23.0 & 1.59 & 0.069 & 86.3 \\
\hline 22 Aug, Sun p.m. & 92 & 25.4 & 1.98 & 0.078 & 97.5 \\
\hline 24 Aug, Tue a.m. & 92 & 16.7 & 1.40 & 0.084 & 105 \\
\hline 24 Aug, Tue p.m. & 101 & 19.1 & 2.51 & 0.131 & 164 \\
\hline 25 Aug, Wed a.m. & 92 & 18.9 & 1.35 & 0.071 & 88.8 \\
\hline 25 Aug, Wed p.m. & 102 & 30.4 & 3.05 & 0.100 & 125 \\
\hline 28 Aug, Sat a.m. & 72 & 25.9 & 1.09 & 0.042 & 52.5 \\
\hline 29 Aug, Sun a.m. & 70 & 10.7 & 0.51 & 0.048 & 60.0 \\
\hline Mean & & 21.3 & 1.69 & 0.078 & 97.5 \\
\hline Median & & 21.1 & 1.50 & 0.075 & 93.8 \\
\hline Values from Gentner et al. (2012) & & & & 0.039 & 48.8 \\
\hline
\end{tabular}

\subsection{Potential explanations}

\subsubsection{Emission factor uncertainty}

Given the discrepancy between predictions and observations of aggregate SOA mass yields shown in Fig. 3a, one deduces that for SOA predictions and observations to match (i.e., for the black and green lines in Fig. 3 a to cross at $f_{\text {gas }}=0.87$ ), (1) the predicted aggregate SOA mass yield (green line) must be higher, or (2) the required SOA mass yield (black line) must be lower, or both (1) and (2) are true. One way by which the required composite SOA mass yield decreases is via an overall increase in the ratio of $\mathrm{EF}_{\mathrm{GPOM}} / \mathrm{EF}_{\mathrm{CO}}$, either by reducing $\mathrm{EF}_{\mathrm{CO}}$ and/or increasing $\mathrm{EF}_{\mathrm{GPOM}}$. To assess the accuracy of the emission factors reported in Gentner et al. (2012), we consider those reported in Fujita et al. (2012) given in Table 2. During August 2010, Fujita et al. (2012) measured emission factors for CO and total (products of incomplete combustion + noncombusted hydrocarbons + evaporative emissions) nonmethane hydrocarbons (NMHC) obtained from tunnel measurements in Van Nuys, California, which is $\sim 32 \mathrm{~km}$ west of the Pasadena ground site. Based on the results presented in Fujita et al. (2012) (Table 2), emission ratios measured in the Van Nuys tunnel range from 52.5 to $164 \mu \mathrm{g} \mathrm{NMHC} \mathrm{sm}{ }^{-3}$ (ppmvCO) $)^{-1}$, with an average value of $97.5 \mu \mathrm{g} \mathrm{NMHC} \mathrm{sm}^{-3}$ (ppmvCO) ${ }^{-1}$. Similarly to Gentner et al. (2012), Fujita et al. (2012) derived these fleet-average emission factors from vehicles traveling through a tunnel at near-constant speeds of approximately $40 \mathrm{mph}$, and excluded cold-start emissions, idle emissions, and diurnal and hotsoak evaporative hydrocarbon emissions. The Gentner et al. (2012) value is consistent with the lower end of the values reported in Fujita et al. (2012). The spread of values reported by Fujita et al. (2012) is most likely attributable to the fact that the emission factors derived include products of incom- plete combustion and evaporative emissions during stabilized running conditions.

We examine the sensitivity of the required composite SOA mass yield by increasing the $\mathrm{EF}_{\mathrm{GPOM}}$,gas reported by Gentner et al. (2012) by a factor of 2.35, which increases the total $\mathrm{EF}_{\mathrm{GPOM}, \mathrm{CO}}$ given by Eq. (13) by a factor of 2 (increasing $\mathrm{EF}_{\mathrm{GPOM}}$, CO from 48.9 to $98.3 \mu \mathrm{g} \mathrm{GPOM} \mathrm{sm}{ }^{3}$ (ppmv $\mathrm{CO})^{-1}$ at $87 \%$ gasoline and $13 \%$ diesel) to match the mean value reported by Fujita et al. (2012) (Fig. 3b). As shown in Fig. $3 b$, increasing $\mathrm{EF}_{\mathrm{GPOM}}$,gas by a factor of 2.35 reduces the required SOA mass yields. However, this also reduces the predicted yields, since the SOA yield from pure gasoline is lower and since the gasoline terms in Eq. (17) have a larger impact than the diesel terms. The net result is that the required and predicted yields still match if the fuel usage is $3 \%$ gasoline and $97 \%$ diesel, and the propagated error bars still intersect when the fuel usage is $40 \%$ gasoline and $60 \%$ diesel. Note that if the $\mathrm{EF}_{\mathrm{GPOM}}$,gas were increased even further, the predicted yield (Eq. 17) would asymptotically approach $Y_{\text {gas }}$ and the required yield would approach zero (Eq. 16). In this analysis, we have assumed the evaporative emissions and products of incomplete combustion have the same SOA mass yield as the tail-pipe exhaust emissions. However, evaporative emissions will be enriched in small alkanes under ambient conditions. According to Fig. 2 of Gentner et al. (2012), the SOA mass yield of evaporative emissions is expected to be lower than tail-pipe emissions by a factor of $\sim 10$. Therefore, this analysis represents a conservative upper limit since evaporative emissions are not expected to contribute substantially to the SOA budget. The SOA formation potential of products of incomplete combustion and incomplete catalytic converter oxidation are examined more thoroughly in Sect. 3.2.4.

McDonald et al. (2013) recently assessed long-term trends (1990-2010) in $\mathrm{EF}_{\mathrm{GPOM}, \mathrm{CO}}$ emission ratios for several US 
Table 3. Gasoline vehicle-specific emission ratios, $\mathrm{EF}_{\mathrm{NMHC}} / \mathrm{EF}_{\mathrm{CO}}$, predicted by EMFAC2011 (http://www.arb.ca.gov/emfac/) for the South Coast Air Basin in summer 2010. Emission ratios are based on daily CO and NMHC emission rates calculated by EMFAC2011. Emission ratios include all drive-cycle components (i.e., running, idle, start, diurnal evaporative, hot-soak evaporative, running evaporative, and resting evaporative). Rows are ordered in descending population. Numerical values in $\mu \mathrm{g} \mathrm{NMHC} \mathrm{m^{-3 }}$ (ppmv CO) ${ }^{-1}$ columns are calculated using the conversion factor $1250 \mu \mathrm{g} \mathrm{CO} \mathrm{sm}^{-3}\left(\mathrm{ppmv} \mathrm{CO}^{-1}\right.$. Note that the values predicted by EMFAC are higher than what is reported by Gentner et al. (2012) because they include products of incomplete combustion, evaporative emissions, and start emissions.

\begin{tabular}{|c|c|c|c|}
\hline Vehicle Class* & $\begin{array}{l}\text { g NHMC } \\
\left(\mathrm{g} \mathrm{CO}^{-1}\right.\end{array}$ & $\begin{array}{l}\mu \mathrm{g} \mathrm{NMHC} \mathrm{sm}^{-3} \\
(\mathrm{ppmv} \mathrm{CO})^{-1}\end{array}$ & Population \\
\hline Values from & 0.031 & 38.3 & Caldecott \\
\hline Gentner et al. (2012) & & & Tunnel \\
\hline LDA & 0.116 & 145 & 5566383 \\
\hline LDT2 & 0.093 & 116 & 1806334 \\
\hline MDV & 0.081 & 101 & 1474925 \\
\hline LDT1 & 0.112 & 140 & 655343 \\
\hline LHD1 & 0.115 & 144 & 257882 \\
\hline MCY & 0.161 & 201 & 213296 \\
\hline $\mathrm{MH}$ & 0.035 & 43.8 & 58258 \\
\hline LHD2 & 0.112 & 140 & 27933 \\
\hline T6TS & 0.096 & 120 & 22177 \\
\hline OBUS & 0.088 & 110 & 7278 \\
\hline UBUS & 0.100 & 125 & 1766 \\
\hline T7IS & 0.051 & 63.8 & 1501 \\
\hline SBUS & 0.068 & 85.0 & 1491 \\
\hline
\end{tabular}

urban areas. As shown in Fig. 3b of McDonald et al. (2013), owing to differences in driving conditions and engine loads, the $\mathrm{EF}_{\mathrm{GPOM}} \mathrm{CO}$ emission ratios derived from tunnel measurements such as those of Gentner et al. (2012) and Fujita et al. (2012) may be lower than those derived from on-road studies in Los Angeles by a factor of 2.7. Therefore, to determine the upper limit of $\mathrm{EF}_{\mathrm{GPOM}, \mathrm{CO}}$ that should be used in this analysis, we increase the overall (gas + diesel) $\mathrm{EF}_{\mathrm{GPOM}, \mathrm{CO}}$ (Eq. 13) by a factor of 2.7. Doing so reduces the required yield (Eq. 14) by a factor of $0.37\left(Y_{\text {req }}=0.37 \times 108.7 \%=\right.$ $40.2 \%$ ). As shown in Fig. $3 \mathrm{c}$, when the overall $\mathrm{EF}_{\mathrm{GPOM}, \mathrm{CO}}$ is increased by a factor of 2.7 , the predicted and required yields match if the fuel usage is $35 \%$ gasoline and $65 \%$ diesel, and the propagated uncertainties intersect if the fuel usage is $65 \%$ gasoline and $35 \%$ diesel.

Given the lack of agreement between predicted and required SOA mass yields (Fig. 3) when using the emission ratios from Fujita et al. (2012), Gentner et al. (2012), and McDonald et al. (2013), if the SV-OOA / $\triangle \mathrm{CO}$ enhancements shown in Fig. 1c are primarily attributable to vehicular emissions, at least one of the following must be true: (1) vehicular emission rates of gas-phase organic mass (relative to $\mathrm{CO}$ ) are substantially larger than those recently measured; or (2) the SOA mass yields of pure gasoline and pure diesel exhaust are substantially (i.e., a factor of $\sim 3-16$ ) higher than what has been measured previously. In the next section, we explore possibility (1) in the context of drive-cycle phases (e.g., cold-start emissions, idle emissions, hot-soak evapora- tive emissions, diurnal evaporative emissions, etc.) that were not the focus of the analysis by Gentner et al. (2012), but are assessed more closely in this study.

\subsubsection{Emission ratios from other drive-cycle phases}

By sampling emissions within urban tunnels for sufficient periods of time, Fujita et al. (2012) and Gentner et al. (2012) estimated average emission factors. However, neither study included emissions from drive-cycle phases other than stabilized running in the emission factors used in this study. To estimate the impact of drive-cycle phase on emission-factor ratio, we use the California EMission FACtor model (EMFAC2011, http://www.arb.ca.gov/emfac/) combined with summer 2010 data for the South Coast Air Basin (SoCAB) of California. Emission factors are weighted and aggregated by vehicle-year populations and speed distributions, and include all drive-cycle components (i.e., running, idle, start, diurnal evaporative, hot-soak evaporative, running evaporative, and resting evaporative). Emission factor ratios, based on daily-average emission rates, for all EMFAC2011 gasoline and diesel vehicle types are given in Tables 3 and 4 , respectively. As shown in Table 3, EMFAC2011 predicts gasoline emission-factor ratios that are generally consistent with the values reported by Fujita et al. (2012) and are $\sim 2-3.5$ times higher than the value reported by Gentner et al. (2012). Based on the results shown in Fig. 3b, increasing the gasoline emission-factor ratio by $\sim 2.5$ reduces both the 
predicted and required SOA mass yields, which does not improve agreement. As shown in Table 4, the diesel emissionfactor ratios predicted by EMFAC2011 are very similar to the value reported by Gentner et al. (2012). These results show that the required and predicted yields do not match even if all drive-cycle phases are accounted for. Therefore, one concludes that either the SOA mass yields for gasoline and diesel exhaust are significantly higher than what has been previously reported, or nonvehicular source categories contribute significantly to the anthropogenic fossil OOA budget measured at the Pasadena ground site. Both of these possibilities are explored in the next section.

\subsubsection{Ambient NMHC / $\Delta$ CO ratios}

The analysis up to this point has been based on measured and predicted NMHC / CO vehicular emission ratios and measured ambient OOA / $\triangle \mathrm{CO}$ ratios at the Pasadena ground site. This analysis is now extended to include all upwind NMHC source categories (vehicular and nonvehicular) by comparing measured ambient NMHC / $\triangle \mathrm{CO}$ ratios to measured ambient OOA / $\triangle \mathrm{CO}$ at the Pasadena ground site. The four main source categories of NMHC in southern California, not including trans-Pacific transport, which is thought to be unimportant for SOA formation in the L.A. Basin due to long transport times and intense dilution, are stationary, area-wide, mobile, and natural (nonfossil). Based on the 2009 Almanac Emission Projection Data reported by the CARB (http://www.arb.ca.gov/app/emsinv/emssumcat.php), the 2010 annual emissions of reactive organic gas (ROG) and $\mathrm{CO}$ from each source are given in Table 5. Note that CARB reports ROG emission rates, which are similar to NMHC but do not include several low-reactive organic compounds such as ethane, acetone, CFCs, and HCFCs. As shown in Table 5, on-road motor vehicles are reported to contribute $\sim 27-29 \%$ of all ROG emissions in the South Coast Air Basin and Los Angeles County. Mobile sources other than on-road vehicles (e.g., aircraft, trains, ocean-going vessels, and off-road equipment such as forklifts) are reported to contribute $\sim 21 \%$ of the ROG emissions.

Figure 4 shows two lumped NMHC concentrations (e.g., single-ring aromatics and small alkanes), normalized by $\Delta \mathrm{CO}$, as functions of photochemical age. See Table 6 for a list of all compounds included in Fig. 4. As shown in Fig. 4, similarly to the roughly linear increases in OOA / $\triangle \mathrm{CO}$ with increasing photochemical age, gas-phase alkane $\left(\mathrm{C}_{6}, \mathrm{C}_{9}-\right.$ $\mathrm{C}_{11}$ ) and single-ring aromatic concentrations both exhibit roughly linear decreases with increasing photochemical age. Note that adding the normalized alkanes and single-ring aromatic concentrations at zero photochemical age suggests an emission ratio of $\sim 55 \mu \mathrm{g} \mathrm{GPOM} \mathrm{sm}{ }^{-3}\left(\mathrm{ppmv} \mathrm{CO}^{-1}\right.$, which is similar to the estimated emission ratio given by Eq. (13). Although this is not proof, the linear decrease in normalized NMHC concentrations with photochemical age, and the similarity between estimated emission ratios are both con-

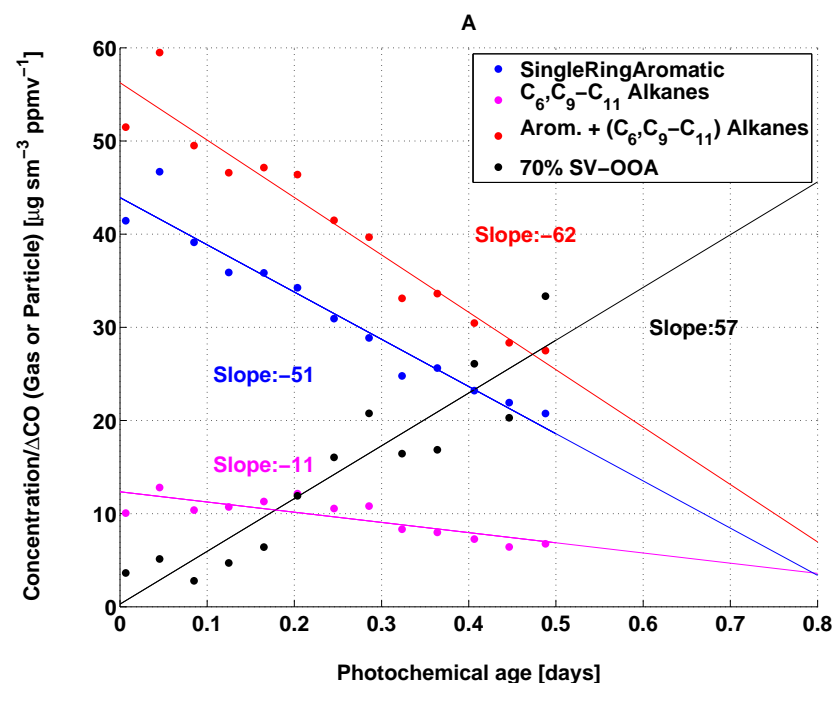

Fig. 4. Measured PMF OOA factor concentrations normalized by $\mathrm{CO}$ enhancement $(\triangle \mathrm{CO}$ is the ambient $\mathrm{CO}$ minus the estimated background $\mathrm{CO}, 105 \mathrm{ppb}$ ) as functions of photochemical age. Also shown are lumped gas-phase VOC concentrations normalized by $\Delta \mathrm{CO}$. See Table 6 for the chemical speciation of each lumped species.

sistent with vehicular exhaust being the dominant source of these compounds. Furthermore, in contrast to the numbers given in Table 5, Borbon et al. (2013) found that emissions from gasoline-powered vehicles dominated the urban anthropogenic NMHC budget during CalNex.

One particularly interesting feature of Fig. 4 is that even if all upwind sources of linear alkanes $\left(\mathrm{C}_{6}, \mathrm{C}_{9}-\mathrm{C}_{11}\right)$ and singlering aromatics are accounted for, the required aggregate SOA mass yield is still $\sim 92 \%(92=\mathrm{OOA} / \triangle \mathrm{CO}$ slope divided by negative NMHC $/ \triangle \mathrm{CO}$ slope $=57 / 62$ ). This required yield may be overestimated because only light straight-chain $\left(\mathrm{C}_{6}, \mathrm{C}_{9}-\mathrm{C}_{11}\right)$ alkane and single-ring aromatic $\left(<\mathrm{C}_{12}\right)$ concentration measurements are available, whereas the majority of alkanes in the ambient are expected to be branched (Fig. 2c). That being said, the required yield of $92 \%$ is still inexplicably large considering that the single-ring aromatic component of vehicular exhaust is expected to produce $\sim 2.5$ times more SOA than the alkane component (Fig. 2c). A similar correspondence between the magnitude of aromatic hydrocarbon decreases and SOA increases was observed by de Gouw et al. (2005) in the 2002 New England Air Quality Study. It is possible that alkanes and aromatics with 12 or more carbon atoms are contributing to the SOA budget. However, alkanes and aromatics $\left(\geq \mathrm{C}_{12}\right)$ attributable to vehicular activity are abundant only in diesel exhaust, and not in gasoline exhaust. If alkanes $\left(\geq C_{12}\right)$ were contributing substantially to the L.A. SOA budget, one would expect to see a significant decrease in OOA concentrations on the weekends when diesel activity is reduced by $\sim 50 \%$. However, this possibility is not supported by the conclusions of 
Table 4. Diesel vehicle-specific emission ratios, $\mathrm{EF}_{\mathrm{NMHC}} / \mathrm{EF}_{\mathrm{CO}}$, predicted by EMFAC2011 (http://www.arb.ca.gov/emfac/) for the South Coast Air Basin in summer 2010. Emission ratios are based on daily CO and NMHC emission rates calculated by EMFAC2011. Emission ratios include all drive-cycle components (i.e., running, idle, start, diurnal evaporative, hot-soak evaporative, running evaporative, and resting evaporative). Rows are ordered in descending population. Numerical values in $\mu \mathrm{g} \mathrm{NMHC} \mathrm{m}{ }^{-3}$ (ppmv CO) $)^{-1}$ columns are calculated using the conversion factor $1250 \mu \mathrm{g} \mathrm{CO} \mathrm{sm}^{-3}(\mathrm{ppmv} \mathrm{CO})^{-1}$.

\begin{tabular}{|c|c|c|c|}
\hline Vehicle Class* & $\begin{array}{l}\text { g NHMC } \\
(\mathrm{g} \mathrm{CO})^{-1}\end{array}$ & $\begin{array}{c}\mu \mathrm{g} \mathrm{NMHC} \mathrm{m}{ }^{-3} \\
(\mathrm{ppmv} \mathrm{CO})^{-1}\end{array}$ & Population \\
\hline Values from Gentner et al. (2012) & 0.224 & 280.0 & Caldecott Tunnel \\
\hline LHD1 & 0.204 & 255 & 80690 \\
\hline T6 instate small & 0.256 & 320 & 37131 \\
\hline LHD2 & 0.203 & 254 & 27901 \\
\hline LDA & 0.225 & 281 & 19184 \\
\hline T6 instate heavy & 0.275 & 344 & 15303 \\
\hline $\mathrm{T} 7$ tractor & 0.219 & 274 & 11037 \\
\hline $\mathrm{MH}$ & 0.261 & 326 & 10110 \\
\hline T7 POLA & 0.198 & 248 & 9818 \\
\hline T7 Single & 0.220 & 275 & 8951 \\
\hline UBUS & 0.217 & 271 & 7084 \\
\hline T6 instate construction small & 0.256 & 320 & 5410 \\
\hline T7 NNOOS & 0.224 & 280 & 5372 \\
\hline T7 CAIRP & 0.227 & 284 & 5325 \\
\hline T6 Public & 0.272 & 340 & 5282 \\
\hline T7 SWCV & 0.232 & 290 & 4839 \\
\hline SBUS & 0.314 & 393 & 4388 \\
\hline T7 Public & 0.267 & 334 & 3579 \\
\hline All Other Buses & 0.278 & 348 & 3178 \\
\hline $\mathrm{T} 7$ single construction & 0.220 & 275 & 3176 \\
\hline $\mathrm{T} 7$ tractor construction & 0.221 & 276 & 2306 \\
\hline T6 instate construction heavy & 0.275 & 344 & 2242 \\
\hline T7 NOOS & 0.231 & 289 & 1939 \\
\hline MDV & 0.205 & 256 & 1504 \\
\hline Motor coach & 0.232 & 290 & 1313 \\
\hline LDT1 & 0.236 & 295 & 953 \\
\hline T6 utility & 0.238 & 298 & 890 \\
\hline LDT2 & 0.245 & 306 & 861 \\
\hline T7 utility & 0.243 & 304 & 423 \\
\hline T7 CAIRP construction & 0.227 & 284 & 392 \\
\hline $\mathrm{T} 7 \mathrm{Ag}$ & 0.217 & 271 & 231 \\
\hline T6 Ag & 0.291 & 364 & 187 \\
\hline T6 CAIRP small & 0.244 & 305 & 136 \\
\hline T6 OOS small & 0.244 & 305 & 78 \\
\hline T6 CAIRP heavy & 0.258 & 323 & 44 \\
\hline T6 OOS heavy & 0.258 & 323 & 25 \\
\hline
\end{tabular}

Hayes et al. (2013) and Bahreini et al. (2012), or the emission ratio analysis presented in this study.

\subsubsection{Incomplete combustion/catalytic converter oxidation products}

The analysis presented thus far is based on the assumption that unburned fuel in exhaust emissions is the dominant source of newly formed SOA attributable to vehicular activity (Gentner et al., 2012). However, recent work suggests that products of incomplete combustion and products of incomplete catalytic converter oxidation may be efficient SOA precursors. Specifically, Gordon et al. (2013) used a laboratory chamber to investigate SOA formation from photooxidation of tail-pipe emissions from 15 light-duty gasoline vehicles (LDGVs) spanning a wide range of types, model years and emission standards. The 15 LDGVs are grouped according to model year into three vehicle classes termed preLEV (LDGVs manufactured prior to 1995), LEV1 (LDGVs manufactured between 1995 and 2003), and LEV2 (LDGVs 
Table 5. CARB 2010 estimated daily emission rates (annual average). Units are in metric-tons per day.

\begin{tabular}{|c|c|c|c|c|}
\hline \multirow[t]{2}{*}{ Source } & \multicolumn{2}{|c|}{ Los Angeles County } & \multicolumn{2}{|c|}{ South Coast Air Basin } \\
\hline & $\mathrm{CO}$ & $\mathrm{ROG}^{*}$ & $\mathrm{CO}$ & ROG $^{*}$ \\
\hline \multicolumn{5}{|l|}{ Stationary sources } \\
\hline Fuel combustion & $24.1(1.3 \%)$ & $4.3(1.1 \%)$ & $34.1(1.1 \%)$ & $5.8(0.9 \%)$ \\
\hline Waste disposal & $0.8(0 \%)$ & $0.9(0.2 \%)$ & $1.1(0 \%)$ & $9.1(1.4 \%)$ \\
\hline Cleaning and surface coatings & $0.0(0 \%)$ & $25.8(6.6 \%)$ & $0.1(0 \%)$ & $40.7(6.1 \%)$ \\
\hline Petroleum production and marketing & $8.9(0.5 \%)$ & $25.1(6.4 \%)$ & $8.9(0.3 \%)$ & $33.2(5.0 \%)$ \\
\hline Industrial processes & $1.3(0 \%)$ & $11.6(3.0 \%)$ & $2.5(0 \%)$ & $20.2(3.0 \%)$ \\
\hline Total stationary sources & $35.0(1.9 \%)$ & $67.7(\mathbf{1 7 . 3 \%})$ & $46.8(1.5 \%)$ & $109.0(\mathbf{1 6 . 5})$ \\
\hline \multicolumn{5}{|l|}{ Area-wide sources } \\
\hline Solvent evaporation & $0(0 \%)$ & $82.7(21.2 \%)$ & $0(0 \%)$ & $129.4(19.5 \%)$ \\
\hline Miscellaneous processes & $51.2(2.8 \%)$ & $5.4(1.4 \%)$ & $112.3(3.6 \%)$ & $14.7(2.2 \%)$ \\
\hline Total area-wide sources & $51.2(2.8 \%)$ & $88.0(22.5 \%)$ & $112.3(3.6 \%)$ & $144.1(21.8 \%)$ \\
\hline \multicolumn{5}{|l|}{ Mobile sources } \\
\hline On-road motor vehicles & $1096.3(60.0 \%)$ & $113.1(29.0 \%)$ & $1817.6(58.4 \%)$ & $182.8(27.6 \%)$ \\
\hline Other mobile sources & $579.5(31.7 \%)$ & $81.0(20.7 \%)$ & $973.2(31.3 \%)$ & $140.1(21.1)$ \\
\hline Total mobile sources & $1675.8(91.7 \%)$ & $194.1(49.7 \%)$ & $2790.8(\mathbf{8 9 . 6} \%)$ & $322.9(48.7 \%)$ \\
\hline \multicolumn{5}{|l|}{ Natural (nonanthropogenic) sources } \\
\hline Natural sources & $65.0(3.6 \%)$ & $40.5(10.4 \%)$ & $164.2(5.3 \%)$ & $86.5(13.1 \%)$ \\
\hline Total natural sources & $65.0(3.6 \%)$ & $40.5(\mathbf{1 0 . 4} \%)$ & $164.2(5.3 \%)$ & $86.5(13.1 \%)$ \\
\hline
\end{tabular}

Table 6. Chemical constituents of lumped species shown in Fig. 4

\begin{tabular}{ll}
\hline Alkanes $\left(\mathrm{C}_{6}, \mathrm{C}_{9}-\mathrm{C}_{11}\right)$ & Single-ring aromatics \\
\hline$n$-hexane & benzene \\
$n$-nonane & toluene \\
$n$-decane & $o$-xylene \\
$n$-undecane & $m$-xylene \\
& $p$-xylene \\
& 1 -ethyl benzene \\
& styrene \\
& isopropyl benzene \\
& $n$-propyl benzene \\
& 1 -ethyl 2-methyl benzene \\
& 1 -ethyl 3-methyl benzene \\
& 1 -ethyl 4-methyl benzene \\
& $1,2,3$-trimethylbenzene \\
& $1,2,4$-trimethylbenzene \\
& $1,3,5$-trimethylbenzene \\
\hline
\end{tabular}

manufactured 2004 or later). For each vehicle class, Gordon et al. (2013) report median emission factors for $\mathrm{CO}$, median emission factors for all nonmethane organic gases (NMOG), median emission factors for speciated and nonspeciated organic gases that are expected to be SOA precursors, and aggregate SOA mass yields required to obtain mass closure for each chamber experiment $\left(Y_{\text {veh.class }}^{\mathrm{SOA}}\right)$. These quantities include products of incomplete combustion and catalytic conversion, and are given in Table 7 for reference.

We first calculate a fleet-average LDGV NMOG emission factor based on the values reported by Gordon et al. (2013) (see Table 7):

$$
\begin{aligned}
\mathrm{EF}_{\mathrm{NMOG}}^{\text {fleet }} & =(\text { Fleet Fraction, preLEV }) \times \mathrm{EF}_{\mathrm{NMOG}}^{\mathrm{preLEV}} \\
& +(\text { Fleet Fraction, LEV1 }) \times \mathrm{EF}_{\mathrm{NMOG}}^{\mathrm{LEV} 1} \\
& +(\text { Fleet Fraction, LEV2 }) \times \mathrm{EF}_{\mathrm{NMOG}}^{\mathrm{LEV} 2} \\
\mathrm{EF}_{\mathrm{NMOG}}^{\text {fleet }} & =0.07 \times 4.5 \mathrm{~g} \mathrm{NMOG}\left(L_{\mathrm{gas}}\right)^{-1} \\
& +0.36 \times 1.3 \mathrm{~g} \mathrm{NMOG}\left(L_{\mathrm{gas}}\right)^{-1} \\
& +0.57 \times 0.4 \mathrm{~g} \mathrm{NMOG}\left(L_{\mathrm{gas}}\right)^{-1} \\
\mathrm{EF}_{\mathrm{NMOG}}^{\text {fleet }} & =1.01 \mathrm{~g} \mathrm{NMOG}\left(L_{\mathrm{gas}}\right)^{-1} .
\end{aligned}
$$

The total NMOG emission factor for the LDGV fleet reported by Gordon et al. (2013) (Eq. 20) is similar to the value reported in McDonald et al. (2013), and is roughly a factor of $\sim 2$ higher than that reported by Gentner et al. (2012). These differences in emission factors are most likely attributable to the differences in LDGV driving conditions in each study.

In a similar manner, we calculate a fleet-average LDGV $\mathrm{CO}$ emission factor based on the values reported by Gordon 
Table 7. Median emission factors and SOA mass yields reported in Gordon et al. (2013). These values include products of incomplete combustion and products of incomplete catalytic converter oxidation.

\begin{tabular}{lrrr}
\hline & preLEV & LEV1 & LEV2 \\
\hline Median EF $_{\text {CO }}\left(\mathrm{gCO} L_{\text {gas }}{ }^{-1}\right)$ & 210 & 25 & 9 \\
Median EF $_{\text {NMOG }}\left({\mathrm{gNMOG} L_{\text {gas }}}^{-1}\right)$ & 4.5 & 1.3 & 0.40 \\
LDGV-fleet fraction $^{*}\left(\mathrm{~g} \mathrm{~g}^{-1}\right)$ & 0.07 & 0.36 & 0.57 \\
Effective SOA mass yield & 0.008 & $0.03-0.17$ & $0.07-0.25$ \\
& $(0.008)$ & $(0.10)$ & $(0.16)$ \\
\hline
\end{tabular}

* Values in parentheses are the arithmetic mean of the reported SOA mass yield range.

et al. (2013) (see Table 7):

$\mathrm{EF}_{\mathrm{CO}}^{\text {fleet }}=21.6 \mathrm{~g} \mathrm{CO}\left(L_{\mathrm{gas}}\right)^{-1}$.

The fleet-average CO emission factor given by Eq. (21) is $\sim 50 \%$ larger than the value reported by Gentner et al. (2012) (Eq. 3).

To facilitate a consistent comparison with the analysis presented in Gentner et al. (2012), the SOA mass yields presented in Gordon et al. (2013) have been rescaled based on the total NMOG tail-pipe emissions and not the fraction of NMOG emissions that is expected to be comprised of SOA precursors (Prec). Therefore, the SOA mass yields reported in Table 7 are roughly half as large as those reported in Fig. 7 of Gordon et al. (2013).

$$
\begin{aligned}
Y_{\text {preLEV }} & =(2 \%) \times(0.38 \mathrm{~g} \mathrm{SOA} \text { Prec } / \mathrm{g} \mathrm{NMOG})=0.8 \% \\
Y_{\mathrm{LEV} 1} & =(6-33 \%) \times(0.51 \mathrm{~g} \text { SOA Prec } / \mathrm{g} \text { NMOG }) \\
& =10 \%((3 \%+17 \%) / 2), \\
Y_{\mathrm{LEV} 2} & =(15-50 \%) \times(0.49 \mathrm{~g} \text { SOA Prec } / \mathrm{g} \text { NMOG }) \\
& =16 \%((7 \%+25 \%) / 2),
\end{aligned}
$$

where the (SOA Prec/NMOG) conversion factors are taken directly from Fig. 3 of Gordon et al. (2013). Using these values, a fleet-average SOA emission factor can also be approximated:

$$
\begin{aligned}
& \mathrm{EF}_{\mathrm{SOA}}^{\text {fleet }}=(\text { Fleet }- \text { Fraction, preLEV }) \times Y^{\mathrm{SOA}_{\mathrm{preLEV}}} \times \mathrm{EF}_{\mathrm{NMOG}}^{\mathrm{preLEV}} \\
& \quad+(\text { Fleet }- \text { Fraction, LEV1 }) \times Y^{\mathrm{SOA}_{\mathrm{LEV} 1}} \times \mathrm{EF}_{\mathrm{NMOG}}^{\mathrm{LEV} 1} \\
& \quad+(\text { Fleet }- \text { Fraction, LEV2 }) \times Y^{\mathrm{SOA}_{\mathrm{LEV} 2}} \times \mathrm{EF}_{\mathrm{NMOG}}^{\mathrm{LEV} 2} \\
& \mathrm{EF}_{\mathrm{SOA}}^{\text {fleet }}=0.07 \times 4.5 \times 0.008 \times \mathrm{g} \mathrm{NMOG}\left(L_{\mathrm{gas}}\right)^{-1} \\
& \quad+0.36 \times 1.3 \times 0.10 \times \mathrm{g} \mathrm{NMOG}\left(L_{\mathrm{gas}}\right)^{-1} \\
& \quad+0.57 \times 0.4 \times 0.16 \times \mathrm{g} \mathrm{NMOG}\left(L_{\mathrm{gas}}\right)^{-1} .
\end{aligned}
$$

Dividing Eq. (26) by Eq. (20) gives an approximate, experimentally derived fleet-averaged SOA mass yield:

$$
\begin{aligned}
& Y^{\mathrm{SOA}_{\mathrm{LDGV}} \text {,fleet }}=\mathrm{EF}_{\mathrm{SOA}}^{\text {fleet }} / \mathrm{EF}_{\mathrm{NMOG}}^{\text {fleet }} \times 100 \%, \\
& Y^{\mathrm{SOA}_{\mathrm{LDGV}, \text { fleet }}}=9 \% .
\end{aligned}
$$

The SOA mass yield given in Eq. (28) is $\sim 4$ times larger than the yield for pure gasoline reported by Gentner et al. (2012) $\left(Y_{\text {gas }}=2.3 \%\right)$. With respect to diesel-fueled vehicle emissions, Jathar et al. (2013) showed that unburned diesel fuel and combustion tail-pipe exhaust from diesel-fueled vehicles have similar SOA formation potentials. As shown in Fig. 4 of Jathar et al. (2013), the experimentally derived aggregate SOA mass yields for diesel exhaust are very similar to the value reported by Gentner et al. (2012) $\left(Y_{\text {dies }}=15 \%\right)$, which suggests that this value is representative of diesel-fueled vehicles in California. However, in this analysis we reduce the $\mathrm{EF}_{\mathrm{NMOG}, \text { dies }}$ to $0.69 \mathrm{~g} \mathrm{NMOG}(\mathrm{L}-\text { dies })^{-1}$ to account for the fraction of nondiesel-particulate-filter-equipped heavyduty diesel vehicles in the South Coast Air Basin, based on discussions in May et al. (2014).

To determine the impact of partial combustion and incomplete catalytic conversion on ambient SOA formation, the analysis presented in Fig. 3a has been redone using the experimentally derived LDGV $\mathrm{EF}_{\mathrm{NMOG}}, \mathrm{EF}_{\mathrm{CO}}$, and the SOA mass yield given in Eqs. 20, 21, and 28, respectively (see Fig. 5a). As shown in Fig. 5a, using the values reported by Gordon et al. (2013) produces results that are qualitatively identical to those shown in Fig. 3. As discussed in the next paragraph, the impact of predicted yield uncertainty is demonstrated via sensitivity analyses. Therefore, the predicted-yield error bars are excluded from Fig. 5a.

To account for the uncertainty associated with the SOA yield scaling technique used above, and to determine the upper limit of the SOA formation potential of gasoline vehicles, we have conducted similar analyses assuming $Y_{\text {gas }}=16 \%$ and $Y_{\text {gas }}=25 \%$, which are the upper limits of the LEV1 and LEV2 vehicle classes, respectively, reported by Gordon et al. (2013). As shown in Fig. S1, although increasing $Y_{\text {gas }}$ to its upper limit does improve agreement to some extent, the predicted and required yields still differ by more than a factor of 3 even when using the highest yields reported by Gordon et al. (2013). To account for the uncertainty associated with calculating the fraction of emitted SOA precursors that have undergone a chemical reaction after 0.45 days of photochemical aging, an additional sensitivity analysis was conducted in which $100 \%$ of the emitted NMOG is assumed to have reacted (see Fig. S2). As shown in Fig. S2, assuming $100 \%$ 


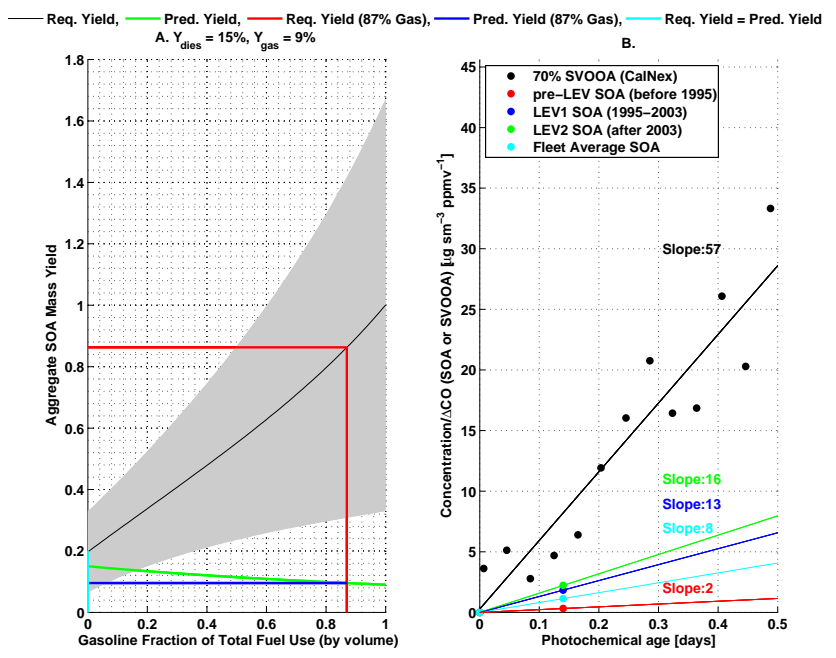

Fig. 5. Same as Fig. 3, except emission factors for gasoline-fueled vehicles and aggregate SOA mass yields are based on the experimentally derived values reported in Gordon et al. (2013). (A) Aggregate SOA mass yield for gasoline exhaust is $9 \%$, which is considered representative of the California LDGV fleet. (B) Measured PMF SV-OOA factor concentrations normalized by $\mathrm{CO}$ enhancement $(\triangle \mathrm{CO}$ is the ambient $\mathrm{CO}$ minus the estimated background $\mathrm{CO}$, $105 \mathrm{ppb}$ ) as functions of photochemical age. Also shown are experimentally derived SOA / $\triangle \mathrm{CO}$ enhancements resulting from photooxidation of tail-pipe emissions from $15 \mathrm{LDGV}$ s recruited from the California in-use fleet. All LDGV experiments were conducted in a portable chamber under urban-like conditions, and all LDGV data are taken directly from Gordon et al. (2013).

conversion of NMOG effectively reduces the required SOA mass yields by a factor of 2 . The predicted yields shown in Fig. S2c are still lower than the required yields by a factor of $\sim 1.7$. We emphasize that there is a significant lack of closure between expected and observed organic aerosol concentrations attributable to fossil-fuel emissions even when assuming $100 \%$ NMOG conversion and an LDGV fleet-averaged SOA mass yield of $25 \%$. Both assumptions are expected to be very unrepresentative of ambient conditions in California.

A more straightforward way to assess the impact of partial combustion and incomplete catalytic conversion on SOA formation from gasoline exhaust is to compare the SOA / $\triangle \mathrm{CO}$ enhancement ratios measured by Gordon et al. (2013) directly to the SV-OOA/ $\triangle \mathrm{CO}$ enhancement ratios measured at the Pasadena ground site during the CalNex field campaign (see Fig. 5b). As shown in Fig. 5b, the SOA / $\triangle \mathrm{CO}$ enhancements for all three LDGV vehicle classes are lower than the CalNex measured value at 0.14 days of photochemical aging. Average SOA/ $\triangle \mathrm{CO}$ enhancement slopes $\left(\mu \mathrm{g} \mathrm{m}^{-3} \mathrm{ppmvCO}^{-1}\right.$ day $\left.^{-1}\right)$ are calculated for each vehicle class by extending a straight line from the origin through the measured data points. As shown in Fig. $5 b$, the average SV-OOA/ $\triangle \mathrm{CO}$ enhancement slope $\left(57 \mu \mathrm{g} \mathrm{m}^{-3} \mathrm{ppmvCO}^{-1} \mathrm{day}^{-1}\right)$ is $\sim 7$ times larger than the fleet-average SOA / $\triangle \mathrm{CO}$ enhancement slope $\left(8 \mathrm{\mu g} \mathrm{m}^{-3} \mathrm{ppmvCO}^{-1} \mathrm{day}^{-1}\right)$, and $\sim 3.5$ times larger than the LEV2 vehicle class slope. Note that the results presented in Fig. 5b are self consistent, and therefore are not influenced by the uncertainty associated with the emission factors and aggregate SOA mass yields reported by Gordon et al. (2013) and Gentner et al. (2012), but they are susceptible to other factors. For instance, Gordon et al. (2013) do not account for loss of organic vapors directly to chamber walls (Matsunaga and Ziemann, 2010). Although highly uncertain, as acknowledged by Gordon et al. (2013), accounting for vapor-phase wall loss would increase their estimated SOA production.

To our knowledge, there is currently no combination of published vehicular emission factors and SOA mass yields derived from laboratory experiments, or measured $\mathrm{SOA} / \triangle \mathrm{CO}$ enhancements based on tail-pipe exhaust emissions that can explain the measurements presented in Fig. 1. Based on the analysis presented in this section, a robust conclusion is that either the SOA mass yields for vehicular tailpipe exhaust are significantly higher than what has been recently reported, or nonvehicular source categories contribute significantly to the anthropogenic fossil OOA budget measured at the Pasadena ground site. For the latter possibility to be true, the nonvehicular fossil emissions must be comprised of compounds other than those listed in Table 6.

\subsubsection{Off-road vehicular emissions}

A large part of this analysis is based on on-road gasoline/diesel fuel sales, and accounting for off-road use of diesel may increase the fraction of total diesel fuel use by several percentage points. However, this is not expected to influence our conclusions because, as shown in Figs. 5, S1, and S2, significant discrepancies exist at virtually all gasoline/diesel fuel usage ratios. In addition, looking at the total mobile sources category in Table 5, which represents the sum of all on-road and off-road mobile emissions, we calculate the emission factor ratio for L.A. and SoCAB both to be $\sim 145 \mu \mathrm{g} \mathrm{ROG} \mathrm{m}{ }^{-3}$ (ppmvCO) ${ }^{-1}$ (still using the $1250 \mu \mathrm{g} \mathrm{CO} \mathrm{sm}^{-3}$ (ppmv CO) ${ }^{-1}$ conversion factor). Assuming that $\sim 50 \%$ of the ROG has reacted after 0.45 days of photochemical aging, and that the aggregate SOA mass yield is $10 \%$, we calculate an SOA enhancement ratio of $7.25 \mu \mathrm{g} \mathrm{SOA} \mathrm{m}^{-3}\left(\mathrm{ppmvCO}^{-1}\right.$. This value is well below the $25 \mu \mathrm{g} \mathrm{SV-OOA} \mathrm{m}{ }^{-3}$ (ppmvCO$^{-1}$ measured during CalNex (Fig. 1). Although this result is consistent with the other results presented in this study, there is considerable uncertainty associated with this calculation, and future work should focus on obtaining detailed speciation profiles and expected SOA mass yields for all major anthropogenic ROG sources in southern California. 


\section{Conclusions}

Using the best available laboratory-derived SOA mass yields, the SV-OOA/ $\triangle \mathrm{CO}$ enhancements attributable to anthropogenic fossil activity (Fig. 1) cannot be explained by the measured and predicted NMOG/CO vehicular emission ratios or the measured ambient NMHC / $\triangle \mathrm{CO}$ ratios. This conclusion is based on the following observations.

- Emission factors and estimated yields reported in Genther et al. (2012), Fujita et al. (2012), McDonald et al. (2013), and calculated using EMFAC2011 significantly underpredict OOA / $\triangle \mathrm{CO}$ enhancements when compared to CalNex observations.

- Accounting for emissions from all drive-cycle phases (e.g., start, idle, evaporative, running, etc.) does not improve agreement between predicted and required SOA mass yields significantly.

- Accounting for all upwind sources of single-ring aromatics and light alkanes $\left(\mathrm{C}_{6}, \mathrm{C}_{9}-\mathrm{C}_{11}\right)$ does not improve agreement between predicted and required $\mathrm{SOA}$ mass yields significantly.

- Accounting for products of incomplete combustion and products of incomplete catalytic converter oxidation does not improve agreement between predicted and required SOA mass yields significantly.

With respect to the applicability of these results to other major urban areas, ratios of OOA / $\triangle \mathrm{CO}$ for Mexico City and the northeastern US are similar or smaller by about a factor of 2 than those observed in L.A., as reported by Hayes et al. (2013). Ratios of NMHC/ $\triangle \mathrm{CO}$ for emissions in the northeastern United States are very similar to those in the L.A. area (Borbon et al., 2013), while those in Mexico City are higher by about a factor of 2 (Bon et al., 2011). Therefore similar qualitative discrepancies between predicted and required yields, albeit of somewhat lower magnitude, may exist in these urban areas as well.

We return to the question: is it more likely that (1) ambient SOA mass yields are substantially larger than what has been derived experimentally, or (2) vehicular emissions do not dominate SOA concentrations attributable to anthropogenic fossil activity in southern California? Neither possibility can be categorically ruled out; therefore, both options should be explored further, particularly since their implications for SOA control strategies are markedly different.

\section{Supplementary material related to this article is available online at http://www.atmos-chem-phys.net/14/ 2383/2014/acp-14-2383-2014-supplement.pdf.}

Acknowledgements. The authors would like to thank R. Bahreini, D. Gentner, A. Chan, A. Goldstein, and two anonymous reviewers for providing valuable comments. This study was supported by NOAA Climate Program Office's AC4 program, award no. NA13OAR4310058. P. L. Hayes and J. L. Jimenez thank CARB 08-309 and 11-305, DOE (BER/ASR) DE-SC0006035, and a CIRES Visiting Fellowship.

Edited by: S. A. Nizkorodov

\section{References}

Aiken, A. C., DeCarlo, P. F., Kroll, J. H., Worsnop, D. R., Huffman, J. A., Docherty, K. S., Ulbrich, I. M., Mohr, C., Kimmel, J. R., Sueper, D., Sun, Y., Zhang, Q., Trimborn, A., Northway, M., Ziemann, P. J., Canagaratna, M. R., Onasch, T. B., Alfarra, M. R., Prevot, A. S. H., Dommen, J., Duplissy, J., Metzger, A., Baltensperger, U., and Jimenez, J. L.: O/C and OM/OC ratios of primary, secondary, and ambient organic aerosols with high-resolution time-of-flight aerosol mass spectrometry, Environ. Sci. Technol., 42, 4478-4485, 2008.

Allan, J. D., Williams, P. I., Morgan, W. T., Martin, C. L., Flynn, M. J., Lee, J., Nemitz, E., Phillips, G. J., Gallagher, M. W., and Coe, H.: Contributions from transport, solid fuel burning and cooking to primary organic aerosols in two UK cities, Atmos. Chem. Phys., 10, 647-668, doi:10.5194/acp-10-647-2010, 2010.

Atkinson, R. J.: Gas-Phase Tropospheric Chemistry of Volatile Organic Compounds: 1. Alkanes and Alkenes, Phys. Chem. Ref. Data, 26, 215-290, 1997.

Bahreini, R., Middlebrook, A. M., de Gouw, J. A., Warneke, C., Trainer, M., Brock, C. A., Stark, H., Brown, S. S., Dube, W. P., Gilman, J. B., Hall, K., Holloway, J. S., Kuster, W. C., Perring, A. E., Prevot, A. S. H., Schwarz, J. P., Spackman, J. R., Szidat, S., Wagner, N. L., Weber, R. J., Zotter, P., and Parrish, D. D.: Gasoline emissions dominate over diesel in formation of secondary organic aerosol mass, Geophys. Res. Lett., 39, L06805, doi:10.1029/2011GL050718, 2012.

Bon, D. M., Ulbrich, I. M., de Gouw, J. A., Warneke, C., Kuster, W. C., Alexander, M. L., Baker, A., Beyersdorf, A. J., Blake, D., Fall, R., Jimenez, J. L., Herndon, S. C., Huey, L. G., Knighton, W. B., Ortega, J., Springston, S., and Vargas, O.: Measurements of volatile organic compounds at a suburban ground site (T1) in Mexico City during the MILAGRO 2006 campaign: measurement comparison, emission ratios, and source attribution, Atmos. Chem. Phys., 11, 2399-2421, doi:10.5194/acp-11-23992011, 2011.

Borbon, A., Gilman, J. B., Kuster, W. C., Grand, N., Chevaillier, S., Colomb, A., Dolgorouky, C., Gros, V., Lopez, M., Sarda-Esteve, R., Holloway, J. S., Stutz, J., Petetin, H., McKeen, S., Beekmann, M., Warneke, C., Parrish, D. D., and de Gouw, J. A.: Emission ratios of anthropogenic volatile organic compounds in northern mid-latitude megacities: Observations versus emission inventories in Los Angeles and Paris, J. Geophys. Res.-Atmos., 118, 2041-2057, 2013.

California Air Resources Board, Motor Vehicle Emission Factor/Emission Inventory Model - EMFAC 2011, available at: http: //www.arb.ca.gov/msei/msei.htm (last access: 20 June 2013), 2011. 
Calvert, J. G., Atkinson, R., Becker, K. H., Kamens, R. M., Seinfeld, J. H., Wallington, T. J., and Yarwood, G. : The Mechanisms of Atmospheric Oxidation of Aromatic Hydrocarbons, Oxford University Press, New York, 556 pp., 2002.

DeCarlo, P. F., Kimmel, J. R., Trimborn, A., Northway, M. J., Jayne, J. T., Aiken, A. C., Gonin, M., Fuhrer, K., Horvath, T., Docherty, K. S., Worsnop, D. R., and Jimenez, J. L. : Field-Deployable, High-Resolution, Time-of-Flight Aerosol Mass Spectrometer, Anal. Chem., 78, 8281-8289, 2006.

de Gouw, J. A., Middlebrook, A. M., Warneke, C., Goldan, P. D., Kuster, W. C., Roberts, J. M., Fehsenfeld, F. C., Worsnop, D. R., Canagaratna, M. R., Pszenny, A. A. P., Keene, W. C., Marchewka, M., Bertman, S. B., and Bates, T. S.: Budget of organic carbon in a polluted atmosphere: Results from the New England Air Quality Study in 2002, J. Geophys. Res.-Atmos., 110, D16305, doi:10.1029/2004JD005623, 2005.

de Gouw, J. A., Brock, C. A., Atlas, E. L., Bates, T. S., Fehsenfeld, F. C., Goldan, P. D., Holloway, J. S., Kuster,Lerner, B. M., Matthew, B. M., Middlebrook, A. M., Onasch, T. B., Peltier, R. E., Quinn, P. K., Senff, C. J., Stohl, A., Sullivan, A. P., Trainer, M., Warneke, C., Weber, R. J., and Williams, E. J.: Sources of particulate matter in the northeastern United States: 1. Direct emissions and secondary formation of organic matter in urban plumes, J. Geophys. Res.-Atmos., 113, D08301, (last access: 10.1029/2007JD009243), 2008.

Dusanter, S., Vimal, D., Stevens, P. S., Volkamer, R., and Molina, L. T.: Measurements of $\mathrm{OH}$ and $\mathrm{HO}_{2}$ concentrations during the MCMA-2006 field campaign - Part 1: Deployment of the Indiana University laser-induced fluorescence instrument, Atmos. Chem. Phys., 9, 1665-1685, doi:10.5194/acp-9-1665-2009, 2009.

Fujita, E. M., Campbell, D. E., Zielinska, B., Chow, J. C., Lindhjem, C. E., DenBleyker, A., Bishop, G. A., Schuchmann, B. G., Stedman, D. H., and Lawson, D. R.: Comparison of the MOVES2010a, MOBILE6.2, and EMFAC2007 mobile source emission models with on-road traffic tunnel and remote sensing measurements, J. Air Waste Manage., 62, 1134-1149, 2012.

Gentner, D. R., Isaacman, G., Worton, D. R., Chan, A. W. H., Dallmann, T. R., Davis, L., Liu, S., Day, D. A., Russell, L. M., Wilson, K. R., Weber, R., Guha, A., Harley, R. A., and Goldstein A. H.: Elucidating secondary organic aerosol from diesel and gasoline vehicles through detailed characterization of organic carbon emissions, P. Natl. Acad. Sci. USA, 109, 18318-18323, 2012.

Gerbig, C., Schmitgen, S., Kley, D., Volz-Thomas, A., Dewey, K., and Haaks, D. : An improved fast-response vacuum-UV resonance fluorescence CO instrument, J. Geophys. Res.-Atmos., 104, 1699-1704, 1999.

Gilman, J. B., Kuster, W. C., Goldan, P. D., Herndon, S. C., Zahniser, M. S., Tucker, S. C., Brewer, W. A., Lerner, B. M., Williams, E. J., Harley, R. A., Fehsenfeld, F. C., Warneke, C., and de Gouw, J. A.: Measurements of volatile organic compounds during the 2006 TexAQS/GoMACCS campaign: Industrial influences, regional characteristics, and diurnal dependencies of the OH reactivity, J. Geophys. Res.-Atmos., 114, D00F06, doi:10.1029/2008JD011525, 2009.

Gordon, T. D., Presto, A. A., May, A. A., Nguyen, N. T., Lipsky, E. M., Donahue, N. M., Gutierrez, A., Zhang, M., Maddox, C., Rieger, P., Chattopadhyay, S., Maldonado, H., Maricq, M. M., and Robinson, A. L.: Secondary organic aerosol formation exceeds primary particulate matter emissions for light-duty gaso- line vehicles, Atmos. Chem. Phys. Discuss., 13, 23173-23216, doi:10.5194/acpd-13-23173-2013, 2013.

Griffin, R. J., Chen, J., Carmody, K., Vutukuru, S., and Dabdub, D.: Contribution of gas phase oxidation of volatile organic compounds to atmospheric carbon monoxide levels in two areas of the United States, J. Geophys. Res.-Atmos., 112, D10S17, doi:10.1029/2006JD007602, 2007.

Hayes, P. L., Ortega, A. M., Cubison, M. J., Froyd, K. D., Zhao, Y., Cliff, S. S., Hu, W. W., Toohey, D. W, Flynn, J. H., Lefer, B. L., Grossberg, N., Alvarez, S., Rappengluck, B., Taylor, J. W., Allan, J. D., Holloway, J. S., Gilman, J. B., Kuster, W. C., de Gouw, J. A., Massoli, P., Zhang, X., Liu, J., Weber, R. J., Corrigan, A. L., Russell, L. M., Isaacman, G., Worton, D. R., Kreisberg, N. M., Goldstein, A. H., Thalman, R., Waxman, E. M., Volkamer, R., Lin, Y. H., Surratt, J. D., Kleindienst, T. E., Offenberg, J. H., Dusanter, S., Griffith, S., Stevens, P. S., Brioude, J., Angevine, W. M., and Jimenez, J. L.: Organic Aerosol Composition and Sources in Pasadena, California during the 2010 CalNex Campaign , J. Geophys. Res.-Atmos., 118, 9233-9257, doi:10.1002/jgrd.50530, 2013.

Jathar, S. H., Miracolo, M. A., Tkacik, D. S., Donahue, N. M., Adams, P. J., and Robinson, A. L.: Secondary Organic Aerosol Formation from Photo-Oxidation of Unburned Fuel: Experimental Results and Implications for Aerosol Formation from Combustion Emissions, Environ. Sci. Technol., 47, 12886-12893, 2013.

Johnson, D., Utembe, S. R., Jenkin, M. E., Derwent, R. G., Hayman, G. D., Alfarra, M. R., Coe, H., and McFiggans, G.: Simulating regional scale secondary organic aerosol formation during the TORCH 2003 campaign in the southern UK, Atmos. Chem. Phys., 6, 403-418, doi:10.5194/acp-6-403-2006, 2006.

Jimenez, J. L., Canagaratna, M. R., Donahue, N. M., Prevot, A. S. H., Zhang, Q., Kroll, J. H., DeCarlo, P. F., Allan, J. D., Coe, H., Ng, N. L., Aiken, A. C., Docherty, K. S., Ulbrich, I. M., Grieshop, A. P., Robinson, A. L., Duplissy,J., Smith, J. D., Wilson, K. R., Lanz, V. A., Hueglin, C., Sun, Y. L., Tian, J., Laaksonen, A., Raatikainen, T., Rautiainen, J., Vaattovaara, P., Ehn, M., Kulmala, M., Tomlinson, J. M., Collins, D. R., Cubison, M. J., Dunlea, E. J., Huffman, J. A., Onasch, T. B., Alfarra, M. R., Williams, P. I., Bower, K., Kondo, Y., Schneider, J., Drewnick, F., Borrmann, S., Weimer, S., Demerjian, K., Salcedo, D., Cottrell, L., Griffin, R., Takami, A., Miyoshi, T., Hatakeyama,S., Shimono, A., Sun, J. Y., Zhang, Y. M., Dzepina, K., Kimmel, J. R., Sueper, D., Jayne, J. T., Herndon, S. C., Trimborn, A. M., Williams, L. R., Wood, E. C., Middlebrook, A. M., Kolb, C. E., Baltensperger, U., and Worsnop, D. R.: Evolution of Organic Aerosols in the Atmosphere, Science, 326, 1525-1529, 2009.

Kleinman, L. I., Springston, S. R., Daum, P. H., Lee, Y.-N., Nunnermacker, L. J., Senum, G. I., Wang, J., Weinstein-Lloyd, J., Alexander, M. L., Hubbe, J., Ortega, J., Canagaratna, M. R., and Jayne, J.: The time evolution of aerosol composition over the Mexico City plateau, Atmos. Chem. Phys., 8, 1559-1575, doi:10.5194/acp-8-1559-2008, 2008.

Matsunaga, A. and Ziemann, P. J.: Gas-Wall Partitioning of Organic Compounds in a Teflon Film Chamber and Potential Effects on Reaction Product and Aerosol Yield Measurements, Aerosol Sci. Tech., 44, 881-892, 2010.

Matsui, H., Koike, M., Takegawa, N., Kondo, Y., Griffin, R. J., Miyazaki, Y., Yokouchi, Y., and Ohara, T.: Secondary organic 
aerosol formation in urban air: Temporal variations and possible contributions from unidentified hydrocarbons, J. Geophys. Res.Atmos., 114, D04201, doi:10.1029/2008JD010164, 2009.

May, A. A., Nguyen, N. T., Presto, A. A., Gordon, T. D., Lipsky, E. M., Karve, M. ,Gutierrez, A., Robertson, W. H., Zhang, M., Chang, O., Chen, S., Cicero-Fernandez, P., Fuentes, M., Huang, S., Ling, R., Long, J., Maddox, C., Massetti, J., McCauley, E., Na, K., Pang, Y., Rieger, P., Sax, T., Truong, T., Vo, T., Chattopadhyay, S., Maldonado, H., Maricq, M. M., and Robinson, A. L.: Gas- and particle-phase primary emissions from in-use, onroad gasoline, Atmos. Environ., in press, 2014.

McDonald, B. C., Gentner, D. R., Goldstein, A. H., and Harley, R., A.: Long-Term Trends in Motor Vehicle Emissions in U.S. Urban Areas, Environ. Sci. Technol., doi:10.1021/es401034z, accepted, 2013.

Odum, J. R., Hoffmann, T., Bowman, F., Collins, D., Flagan, R. C., and Seinfeld, J. H.: Gas/particle partitioning and secondary organic aerosol yields, Environ. Sci. Technol., 30, 2580-2585, 1996.

Odum, J. R., Jungkamp, T. P. W., Griffin, R. J., Flagan, R. C., and Seinfeld, J. H.: The atmospheric aerosol-forming potential of whole gasoline vapor, Science, 276, 96-99, 1997.

Paatero, P. and Tapper, U.: Positive matrix factorization - a nonnegative factor model with optimal utilization of error-estimates of data values, Environmetrics, 5, 111-126, 1994.

Parrish, D. D., Stohl, A., Forster, C., Atlas, E. L., Blake, D. R., Goldan, P. D., Kuster, W. C., and de Gouw, J. A.: Effects of mixing on evolution of hydrocarbon ratios in the troposphere, J. Geophys. Res.-Atmos., 112, D10S34, doi:10.1002/jgrd.50331, 2007.

Ryerson, P. L., Andrews, A. E., Angevine, W. M., Bates, T. S., Brock, C. A., Cairns, B., Cohen, R. C., Cooper, O. R., de Gouw, J. A., Fehsenfeld, F. C., Ferrare, R. A., Fischer, M. L., Flagan, R. C., Goldstein, A. H., Hair, J. W., Hardesty, R. M., Hostetler, C. A., Jimenez, J. L., Langford, A. O., McCauley, E., McKeen, S. A., Molina, L. T., Nenes, A., Oltmans, S. J., Parrish, D. D., Pederson, J. R., Pierce, R. B., Prather, K., Quinn, P. K., Seinfeld, J. H., Senff, C. J., Sorooshian, A., Stutz, J., Surratt, J. D., Trainer, M., Volkamer, R., Williams, E. J., and Wofsy, S. C.: The 2010 California research at the Nexus of air quality and climate change (CalNex) field study, J. Geophys. Res. Atmos., 118, 5830-5866, doi:10.1002/jgrd.50331, 2013.
Thalman, R. and Volkamer, R.: Inherent calibration of a blue LED-CE-DOAS instrument to measure iodine oxide, glyoxal, methyl glyoxal, nitrogen dioxide, water vapour and aerosol extinction in open cavity mode, Atmos. Meas. Tech., 3, 1797-1814, doi:10.5194/amt-3-1797-2010, 2010.

Ulbrich, I. M., Canagaratna, M. R., Zhang, Q., Worsnop, D. R., and Jimenez, J. L.: Interpretation of organic components from Positive Matrix Factorization of aerosol mass spectrometric data, Atmos. Chem. Phys., 9, 2891-2918, doi:10.5194/acp-9-2891-2009, 2009.

Volkamer, R., Jimenez, J. L., San Martini, F., Dzepina, K., Zhang, Q., Salcedo, D., Molina, L. T., Worsnop, D. R., and Molina, M. J.: Secondary organic aerosol formation from anthropogenic air pollution: Rapid and higher than expected, Geophys. Res. Lett., 33, L17811, doi:10.1029/2006GL026899, 2006.

Warneke, C., deGouw, J. A., Holloway, J. S., Peischl, J., Ryerson, T. B., Atlas, E., Blake, D., Trainer, M., and Parrish, D. D.: Multiyear trends in volatile organic compounds in Los Angeles, California: Five decades of decreasing emissions, J. Geophys. Res.-Atmos., 117, D00V17, doi:10.1029/2012JD017899, 2012.

Zhang, Q., Jimenez, J. L., Canagaratna, M. R., Allan, J. D., Coe, H., Ulbrich, I., Alfarra, M. R., Takami, A., Middlebrook, A. M., Sun, Y. L., Dzepina, K., Dunlea, E., Docherty, K., DeCarlo, P. F., Salcedo, D., Onasch, T., Jayne, J. T., Miyoshi, T., Shimono, A., Hatakeyama, S., Takegawa, N., Kondo, Y., Schneider, J., Drewnick, F., Borrmann, S., Weimer, S., Demerjian, K., Williams, P., Bower, K., Bahreini, R., Cottrell, L., Griffin, R. J., Rautiainen, J., Sun, J. Y., Zhang, Y. M., and Worsnop, D. R.: Ubiquity and Dominance of Oxygenated Species in Organic Aerosols in Anthropogenically-Influenced Northern Hemisphere Mid-latitudes, Geophys. Res. Lett., 34, L13801, doi:10.1029/2007GL029979, 2007.

Zotter, P., El-Haddad, I., Zhang, Y., Hayes, P. L., Zhang, X., Lin, Y., Wacker, L., Schnelle-Kreis, J., Abbaszade, G., Zimmermann, R., Surratt, J. D., Weber, R., Jimenez, J. L., Szidat, S., Baltensperger, U., and Prevot, A. S. H.: Diurnal cycle of fossil and non-fossil carbon using radiocarbon analyses during CalNex, J. Geophys. Res.-Atmos., submitted, 2014. 